American Journal of Biochemistry and Biotechnology 3 (2): 66-86, 2007

ISSN 1553-3468

(C) 2007 Science Publications

\title{
Protein Molecular Structures, Protein SubFractions, and Protein Availability Affected by Heat Processing: A Review
}

\author{
Peiqiang $\mathrm{Yu}$ \\ College of Agriculture and Bioresources, University of Saskatchewan \\ 51 Campus Drive, Saskatoon, S7N 5A8, Canada
}

\begin{abstract}
The utilization and availability of protein depended on the types of protein and their specific susceptibility to enzymatic hydrolysis (inhibitory activities) in the gastrointestine and was highly associated with protein molecular structures. Studying internal protein structure and protein subfraction profiles leaded to an understanding of the components that make up a whole protein. An understanding of the molecular structure of the whole protein was often vital to understanding its digestive behavior and nutritive value in animals. In this review, recently obtained information on protein molecular structural effects of heat processing was reviewed, in relation to protein characteristics affecting digestive behavior and nutrient utilization and availability. The emphasis of this review was on (1) using the newly advanced synchrotron technology (S-FTIR) as a novel approach to reveal protein molecular chemistry affected by heat processing within intact plant tissues; (2) revealing the effects of heat processing on the profile changes of protein subfractions associated with digestive behaviors and kinetics manipulated by heat processing; (3) prediction of the changes of protein availability and supply after heat processing, using the advanced DVE/OEB and NRC-2001 models, and (4) obtaining information on optimal processing conditions of protein as intestinal protein source to achieve target values for potential high net absorbable protein in the small intestine. The information described in this article may give better insight in the mechanisms involved and the intrinsic protein molecular structural changes occurring upon processing.
\end{abstract}

Key words: Molecular chemistry, Synchrotron; Protein structures; $\alpha$-helix; $\beta$-sheet; Protein amides; Protein subfractions; Modeling protein supply; Heat Processing

\section{INTRODUCTION}

Protein and Heat Processing: As we know, protein is one of most important nutrient. Heat processing has been used to improve protein utilization and availability [eg. 1-5] and inactivate antinutrition factors ${ }^{[6]}$ by reducing the solubility of the protein, changing protein subfractions, and reducing rumen fermentation and metabolism, increasing the amounts of protein entering the small intestine for absorption and digestion ${ }^{[1,5,7]}$, and reducing rumen conjugated linoleic acid hydrogenation and increasing the amount of conjugated linoleic acid available in the small intestine ${ }^{[8]}$.

The mechanism of altering the protein digestive behavior with heat processing, summarized by Goelema ${ }^{[1]}$, involves denaturation (which is a disorganization of the overall molecular shape of a protein), unfolding or uncoiling of a coiled or pleated structure, or the separation of the protein into its subunits, which may then unfold or uncoil ${ }^{[9]}$. Any temperature change in the environment of the protein which can influence the non-covalent interactions involved in the structure may lead to an alteration of the protein internal structures ${ }^{[10]}$. Recently research showed that heat processing affected protein moleclualr structures ${ }^{[10]}$ and changed the protein $\alpha$-helix to $\beta$-sheet ratio ${ }^{[10,11]}$. These changes affected nutritive quality and availability ${ }^{[12]}$.

Literatures show that the effects of heat processing on protein value, utilization and availability are equivocal ${ }^{[13]}$. Part of reason was that there was no availability of a newly analytical technique which could be used to detect inherent molecular changes of protein structures by heat processing, and heating conditions may not be optimal, either underheated or overheated. Therefore it was crucially important to develop an advanced analytical technique that can be used to detect molecular structural changes, which are associated with heat processing and to develop the advanced nutritive evaluation models that can quantitatively predict 
nutrient supply and availability changes after heat processing and is able to identify optimal/best processing conditions.

Newly Developed Analytical Techniques and Strategies Used to Study Effect of Heat Processing on Protein Molecular Structure in Relation to Utilization and Availability of Protein: There are three analytical techniques and approaches which could be applied to study effects of heat processing on protein structure, protein utilization and protein availability. The first approach is to use the newly developed, advanced, non-invasive and non-destructive synchrotron based FTIR microspectroscopy (S-FTIRM) as a novel research tool to study protein inherent structures in relation to protein nutritive value and digestive behaviors ${ }^{[14]}$. Checking effects of heat processing on protein quality and availability is to look at magnitude of changes of the protein internal structures in the intrinsic protein structures in terms of $\alpha$-helix to $\beta$-sheet ratio within the intact tissue ${ }^{[10,12,15]}$. The second is to study protein subfractions in relation to rumen degradation characteristics and kinetics to assess protein utilization using the Cornell Net Carbohydrate Protein System (CNCPS) ${ }^{[16]}$. The third is to use advanced protein evaluation models, the DEV/OEB system ${ }^{[17,18]}$ and NRC-2001 model ${ }^{[19]}$ to quantitatively predict potential protein and microbial protein availability and supply affected by heat processing and to determine or identify an optimal processing condition through the models.

Goals and Emphasis of the Review: The goals of this review were to (1) introduce a novel synchrotron-based analytical technique (S-FRIRM) as an emerging method for protein molecular structure research within cellular and subcellular dimensions within intact tissues and (2) review three approaches /strategies for protein structure and availability research.

The emphases of this review are on (1) using the advanced synchrotron technology (S-FTIRM) as a novel approach to reveal protein molecular chemistry affected by heat processing within intact tissues, (2) quantify changes of protein internal structure affected by heat processing using multi-component peak modeling with Gaussian and Lorentzian methods in relation to protein nutritive value; (3) revealing the effects of heat processing on the profile changes of the protein subfractions associated with digestive behaviors and kinetics manipulated by heat processing methods; (4) prediction of changes of potential protein and microbial protein supply after heat processing, using the
DVE/OEB system ${ }^{[18]}$ and NRC-2001 models, and (5) obtaining information on optimal processing conditions of protein as intestinal protein source to achieve target values for potential high net absorbable protein in the small intestine while holding any $\mathrm{N}$ loss in the rumen to a low level, using the above two models.

The information described in this article may give better insight in the mechanisms involved and the structural changes occurring upon processing of protein in terms of protein molecular structures, protein subfraction profiles and protein availability. A focus of the review was on evaluation of the newly developed synchrotron-based analytical technique (S-FTIRM), and new approaches to establishment of a complex protein evaluation system that more accurately accounts for digestive processes on a quantitative basis.

\section{Structural Aspects of Protein Associated With Nutritive Values And Introduction Of Advanced Synchrotron-Based Bioanalytical Technique}

Protein Structures in Relation to Protein Nutritive Value: An understanding of relationships between protein (in terms of total protein composition and protein molecular structures) and protein utilization and availability are very important to economical and sustainable animal productions. Protein quality, degradation characteristics, utilization and availability are closely related to NOT ONLY 1) total protein chemical composition, BUT ALSO 2) protein intrinsic structures (such as protein secondary structures: $\alpha$ helix, $\beta$-sheet and their ratio) ${ }^{[14,20,21]}$, and 3) biological component matrix (such as protein to starch matrix, protein to carbohydrate matrix) ${ }^{[22,23]}$.

Protein Internal Structure: As mentioned before, the nutritive value, digestibility and availability of protein, which are highly associated with protein inherent structures, depend on the type of protein and their specific susceptibility to enzymatic hydrolysis (inhibitory activities) in the gastrointestines. Studying the protein inherent structure leads to an understanding of the components that make up a whole protein ${ }^{[24,25]}$. An understanding of the internal structure of the whole protein is often vital to understanding its digestive behavior, nutritive quality, utilization and availability. Protein internal structures include mainly $\alpha$-helix and $\beta$ sheet, and very small amounts of $\beta$-turn and random coil $[14,25,26]$. The ratios and proportions of these structures influences protein quality, utilization, availability and digestive behavior [10, 14, 21]. High proportion of $\beta$-sheet structure may partly cause low 
access to gastrointestinal digestive enzymes, which results in a low protein value and low protein availability.

However, studies on protein structures and their inherent structural changes in relation to nutritive value and digestive behaviors of protein are extremely rarely. Recent research has shown that different protein sources have different the proportions and ratios of $\alpha-$ helix and $\beta$-sheet in protein structures ${ }^{[21]}$. These protein structures were highly associated with protein nutritive value. The heating processing affects protein structural changes, some resulting in high protein value and some resulting in low protein value ${ }^{[10]}$. It has also been found that the sensitivity of the variety to heat was different and therefore the tissue inherent protein structure changes were different ${ }^{[10]}$.

\section{Traditional "Wet" Chemical Approach Cannot Link} Structure to Chemical Information: Traditional "wet" analytical chemistry usually looks for a specific known component through homogenization and separation of the components of interest from the complex matrix. As a result, the information about the spatial origin and distribution of the component of interest is lost and the object of the analysis is destroyed [27]. Traditional "wet" chemical analyses rely heavily on the use of harsh chemicals and derivatization, therefore altering the native structures and possibly generating artifacts and the analyses also require reasonable amounts of material ( $\mathrm{g}$ or mg levels), which usually means that they are carried out on composite samples [28].

Traditionally, we use the conventional "wet" chemical analysis to determine total chemical composition, and then we use the total chemical composition to predict nutritive and energy values. For example, the NRC dairy and beef ${ }^{[19,29]}$ use a summary chemical approach $[19,30]$ to determine total feed composition (such as crude protein, organic matter, ether extract, acid detergent fiber, neutral detergent fiber, acid detergent insoluble nitrogen, neutral detergent insoluble nitrogen), and then put these basic chemical compositions into the NRC formula to estimate energy values (such as total digestible nutrients (TDN), total digestible neutral detergent fiber (tdNDF), total digestible crude protein (tdCP), total digestible fatty acid (tfFA) and total digestible nonfiber carbohydrate (tdNFC)), and then estimate energy values (such as TDN, DE, ME, NE) [19].

Question we asked was how accurate this chemical approach? So we did some comparison ${ }^{[31]}$. We used a biological approach to directly determine total digestible nutrients, and then obtained the energy values. The results ${ }^{[31]}$ showed that the data were not predictable from both the NRC chemical approach ${ }^{[19,}$ ${ }^{29]}$ and the biological approach. This study ${ }^{[31]}$ indicated that the NRC chemical approach $[19,29]$ could not accurately predict energy values. Why was not predictable? Part of reason is that the NRC chemical approach only considers total chemical composition, but did not consider plant intrinsic structure and biological component matrix, which are also closely related to nutritive value, energy value and protein value. Even two plants have the same total chemical composition, if inherent structures different, the nutritive values are different. For example, Harrington barley and Valier barley which are similar in chemical composition, but digestive behavior and nutrient availability are completely different.

Each plant/seed has unique inherent structure. Therefore their digestive behaviors are different. However, if using the conventional "wet" chemical analysis, we only obtain total chemical composition. No structural-chemical information and molecular features can be obtained. In other words, "wet" chemical approach cannot link structure to chemical information.

\section{Emerging Advanced Synchrotron-Based Bioanalytical Technique for Plant Structure} Research : A synchrotron is a giant particle accelerator that turns electrons into light ${ }^{[32]}$. Synchrotron light is extremely bright (millions of times brighter than sunlight). The beam is non-divergent, intense and extremely fine ${ }^{[33-37]}$. When a synchrotron light (IR) source, FTIR spectroscopy and microscopy combined together, it is called "synchrotron radiation-based FTIR microspectroscopy (S-FTIRM). Recently, the S-FTIRM has been developed as a rapid, direct, non-destructive and non-invasive bioanalytical technique. This technique, taking advantages of synchrotron light brightness (which is usually 100 1000 times brighter than conventional globar source and has small effective source size), is capable of exploring the MOLECULAR chemistry within microstructures of biological samples with high signal to noise ratio at ultra-spatial resolutions as fine as 3 10 $\mu \mathrm{m}^{[26,33-45]}$.

This technique is able to provide information relating to the quantity, composition, structure and distribution of chemical constituents and functional groups in a tissue and can encompass a wider spectral range so that more detailed structural information can be extracted. It can link tissue structural information to chemical information at a cellular and sub-cellular level and is able to provide 4 types of information 
simultaneously, 1) tissue composition, 2) tissue structure, 3) tissue chemistry and 4) tissue environment. This advanced bioanalytical technique, S-FTIRM, has already been used in medical science research, for example comparison of cancer tissue and normal tissue in the molecular structural features. The technique can be used to increase the fundamental understanding of plant internal structures at the cellular level and bring a new level of understanding of analytical information [27]. However, to date there has been very little application of this synchrotron-based bioanalytical technique (S-FTIRM) to the study of the structuralchemical features of plant tissue and protein structure. These structural-chemical features are associated with protein quality and nutritive value ${ }^{[14]}$.

\section{Study Protein Internal Structures Affected By Heat Processing At Cellular and Subcellular Levels In Relation To Protein Values, Using Synchrotron Ftir Microspectroscopy: A Novel Approach}

Unique Protein Bands and Principle of Synchrotron-Based FTIR Microspectroscopy: Each biological component has an unique molecular structural feature, thus each has its own unique IR spectrum, for example lignin band at ca. $1510 \mathrm{~cm}^{-1}$, starch band at ca. $1025 \mathrm{~cm}^{-1}$ and lipid carbonyl $\mathrm{C}=\mathrm{O}$ ester band at ca. $1740 \mathrm{~cm}^{-1}[33,38,42,44,46,47]$. The characteristic of protein structure is unique in the peptide bond. The peptide bond contains $\mathrm{C}=\mathrm{O}, \mathrm{C}-\mathrm{N}$ and $\mathrm{N}-\mathrm{H}$. The protein amide $\mathrm{I}$ bond is primarily $\mathrm{C}=\mathrm{O}$ stretching vibration (80\%) plus C-N stretching vibration. Protein amide I absorbs at ca. $1650 \mathrm{~cm}^{-1}$. Protein amide II which absorbs at $1550 \mathrm{~cm}^{-1}$ consists primarily of $\mathrm{N}-\mathrm{H}$ bending vibrations $(60 \%)$ coupled with C-N stretching vibrations (40\%) ${ }^{[47,48]}$. Typical, protein secondary structures include mainly the $\alpha$-helix and $\beta$-sheet ${ }^{[24,25]}$. Random coil and $\beta$-turn exist in a small amount in the protein secondary structures. The protein IR spectrum has two primary features, as indicated before, the amide I (ca. 1600-1700 $\mathrm{cm}^{-1}$ ) and amide II (ca. 1500-1560 $\mathrm{cm}^{-1}$ ) bands, which arise from specific stretching and bending vibrations of the protein backbone. The amide I band arises predominantly from the $\mathrm{C}=\mathrm{O}$ stretching vibration of the amide $\mathrm{C}=\mathrm{O}$ group. The vibrational frequency of the amide $\mathrm{I}$ band is particularly sensitive to protein secondary structure ${ }^{[35,}$ $36,47,49-51]$ and can be used to predict protein secondary structure. For $\alpha$-helix, the amide I is typically in the range of $1648-1658 \mathrm{~cm}^{-1}$. For $\beta$-sheet, the peak can be found within the range of $1620-1640 \mathrm{~cm}^{-1}{ }^{[50]}$. The amide II (predominantly an $\mathrm{N}-\mathrm{H}$ bending vibration coupled to C-N stretching) is also used to assess protein conformation. However, as it arises from complex vibrations involving multiple functional groups they are less useful for protein structure prediction than the amide I band ${ }^{[47]}$.

Globar Sourced vs. Synchrotron-Based FTIR Microspectroscopy: The detailed comparisons between the conventional globar and synchrotron sourced FTIR microspectroscopy have been reported by Holman et al. ${ }^{[52]}$, Wetzel et al. ${ }^{[33]}$, Miller ${ }^{[35,36]}$, Dumas ${ }^{[26]}$ and $\mathrm{Yu}{ }^{[14]}$. In general, using a standard globar (conventional thermal IR) sourced FTIR microspectroscopy cannot reveal chemical feature of micro-biomaterials, which is $<20$ to $50 \mu \mathrm{m}$ (depend on the type of infrared microspectrometer). The normal plant cell size is around 5-30 $\mu \mathrm{m}$. With globar source, very poor signal to noise ratio within plant cellular dimensions is obtained ${ }^{[26,33,35,36]}$. Using the S-FTIRM allows very small area to be explored (a few microns), provides higher accuracy and precision, allows faster data collection, reaches diffraction limit as a few microns and provides very good signal to noise ratio with highly ultra-spatial resolutions ${ }^{[26,35,36,37,52]}$. It can reveal molecular structural features [20, 21, 23, 31, 42-44]. Synchrotron IR source is unable to damage any biological tissue ${ }^{[50]}$.

\section{Methodology of Advanced Synchrotron-Based FTIR Technique}

Tissue Preparation and Synchrotron Transmission and Reflection FTIR Microspectroscopy: Tissues were cut into thin cross sections (ca. 5 to $10 \mu \mathrm{m}$ thickness). The unstained cross-sections of the tissues rapidly transferred to $\mathrm{BaF}_{2}$ windows (size: $13 \times 1 \mathrm{~mm}$ disk; Spectral Systems, NY) for transmission mode in synchrotron transmission FTIR microspectroscopic work. The unstained cross-sections were dry mounted onto Low-e IR microscope slides (Kevley Technologies, Chesterland, $\mathrm{OH}$ ) for reflectance mode in synchrotron reflection FTIR microspectroscopic work $[42,43]$.

Synchrotron-Based Infrared Microspectroscopy: The spectroscopic images and data were recorded using a Nicolet Magna 860 FTIR (Thermo Nicolet, USA) equipped with a Continu $\mathrm{m}$ IR microscope (Spectra Tech, USA), mapping stage controller, $32 \times$ objective and a mercury cadmium telluride (MCT-A) detector. The bench was configured with a collimated synchrotron light beamline (U2B and U10B at NSLS- 
BNL, New York; Port031 at SRC, Wisconsin) served as an external input to the Thermo Nicolet InstrumentsNicolet Magna 860). The modulated light was passed through the IR microscope to perform transmission or reflection microscopy. The spectra were collected in the mid-IR range of $4000-800 \mathrm{~cm}^{-1}$ at a resolution of $4 \mathrm{~cm}^{-1}$ with 64 scans co-added and an aperture setting of ca. 10 $\mu \mathrm{m} \times 10 \mu \mathrm{m}$. The reasons for the chosen aperture size of $10 \mu \mathrm{m} \times 10 \mu \mathrm{m}$ were: 1 ) The size was within cellular dimension; 2). The $10 \mu \mathrm{m} \times 10 \mu \mathrm{m}$ aperture size was the best for getting good signal to noise ratio spectrum mapping of plant tissues. To minimize IR absorption by $\mathrm{CO}_{2}$ and water vapour in ambient air, the optics could be purged using dry $\mathrm{N}_{2}$. A background spectroscopic image file was collected from an area free of sample. The mapping steps were equal to aperture size. Stage control, data collection and processing were performed using OMNIC 6.0. Scanned visible images were obtained using a charge-coupled device (CCD) camera linked to the infrared images ${ }^{[42,43,44]}$.

Spectrum Data Analysis and Chemical Imaging: The spectral data of the plant tissues were collected, corrected with the background spectrum, displayed in the absorbance mode and analyzed using OMNIC software 6.0. An automatic baseline correction was applied to generate the final spectra. The synchrotron FTIR absorbance was expressed as $\log (1 / \mathrm{R})^{\text {[The spectrum }}$ collected in reflection model needed to transfer to absorbance unit by Log $(1 / \mathrm{R})]$.

The data can be displayed as either as a series of spectroscopic images collected at individual wavelengths, or as a collection of infrared spectra obtained at each pixel position in the image.

Functional groups bands were according to

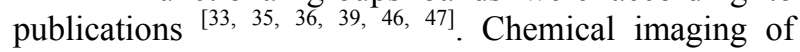
functional groups was determined by the OMNIC software 6.0 or the cluster imaging was determined by the Cytospec ${ }^{[53]}$. Peak ratio images (were obtained by the height or area under one functional group band (such as amide I $1650 \mathrm{~cm}^{-1}$ ) divided by the height or area under another functional group band (such as starch $1025 \mathrm{~cm}^{-1}$ ) at each pixel, which representing biological component ratio intensity and distribution in the plant tissues (e.g. protein-to-total-starch-ratio image and hemicellulose-to-total-carbohydrate ratio image). The false color maps were used, which were derived from the area under particular spectral features ${ }^{[42,43,44]}$. With the synchrotron based analytical technique-S-FTIRM, chemical intensities and distributions of biological components such as lignin, cellulose, protein, lipid and total carbohydrate and their ratios (such as protein to carbohydrate; Cellulose to carbohydrate ratio) could be mapped. These images revealed the chemical information of tissue intrinsic structure. Such information could be analyzed for clues of the plant intrinsic structures in relation to biodegradation characteristics, used to identify the chemical differences between plant varieties in a specific structure (such as comparing aleurone layer or comparing see coat) without the destruction of the tissue, or used to identify the molecular structural changes of the tissues affected by physical, chemical and biological treatments.

\section{Quantify the Proportions of $\alpha$-Helix and $\beta$-Sheet (IR absorption Intensity) in Protein Secondary Structures}

Selection of the Relatively "Pure" Protein Areas in Tissues: The ultra-spatially chemical mapping of protein and protein to other biological component ratio (such as protein to starch ratio) provided spectra data selected with relatively "pure" protein body for modeling protein amide I component peaks. The selection procedure of the relatively "pure" protein in the plant tissues followed the methodology (called "cherry pick-up") published by Wetzel et al. ${ }^{[51]}$. The brief procedure is as follows:

Within each image, multi-areas samples with the relatively "pure" protein were selected for quantification of protein secondary structures (such as $\alpha$-helix to $\beta$-sheet ratio) ${ }^{[51]}$. This is because the tissue matrix is heterogeneous. Protein and protein to starch ratio unequally distributed in the plant tissues to justify to select pure protein for molecular structural analysis. The selected spectrum had very high protein amide I and amide II peaks with no or very little carbohydrate $[44,54]$. In order to eliminate carbohydrate scattering effect on the protein spectrum, the relatively "pure" protein areas were selected for protein secondary structure analysis. The size of each probed area was 10 $\mu \mathrm{m} \times 10 \mu \mathrm{m}$, which was within plant cellular dimensions $(5 \text { to } 30 \mu \mathrm{m})^{[10,54,55]}$.

Quantify the Relatively Proportions of Protein Secondary Structures : Because protein amide I component bands were overlapped ${ }^{[10]}$, a specific multipeaks fitting or modeling procedure was required. To determine the relative amounts of $\alpha$-helix and $\beta$-sheet of the protein secondary structures in pure protein areas, two steps were applied. The first step was using Fourier self-deconvolution (FSD) to obtain the FSD spectrum in protein amide I region to identify protein amide I component peak frequencies. The detailed concepts and 
algorithm of FSD (FSD: a method for resolving intrinsically overlapped bands) were described in Kauppinen et al. ${ }^{[56]}$ and Griffths and Pariente ${ }^{[57]}$. The second step was using multi-peaks fitting program with Gaussian and Lorentzian functions ${ }^{[58]}$ using Origin data analysis software to quantify the multi-component peak areas in protein amide I bands. The differences and comparisons between Gaussian and Loretzian functions for multi-component peak fitting and sample curves are studied in $\mathrm{Yu}{ }^{[58]}$. The detailed descriptions of peak shape, centre, offset, wide and areas were reported in Origin. The relative amount of $\alpha$-helix and $\beta$-sheet based on modeled peak areas was calculated according to the report generated by the software. It needs to be mentioned that the relative proportions of protein secondary structure may not reflect the natural secondary structure. However, the purpose of modeling the relative proportions of secondary structure was to detect the tissue differences, and processing effects between plants and relation to nutritive value and digestive behavior. It needs to be mentioned that multipeak modeling procedure is only fine when we estimate relative proportion (not exact proportions) of protein structure profiles

Univariate and Multivariate Statistical Approaches for Synchrotron FTIR Spectrum Data: Statistical approaches to analyze spectral data collected under the S-FTIRM usually include uni- and multivariate statistical methods. The univariate methods of analysis consist of various mapping displays of spectral data. Usually researchers may select band intensities, integrated intensities, band frequencies, band intensity ratios etc, to construct false color maps of the spectral data ${ }^{[36]}$.

The multivariate methods of data analyses create spectral corrections and maps by including not just one intensity or frequency point of a spectrum, but by utilizing the entire spectral information. The methods include cluster analysis (CLA) ${ }^{[53]}$ and principal component analysis (PCA), which are techniques which clusters infrared spectra in a map based on similarity with other spectra in the same map $[36,59,60]$.

Hierarchical Cluster Analysis to Identify Intrinsic Structural Difference: The first multivariate analysis, is agglomerative hierarchical cluster analysis, of which function performs an (agglomerative hierarchical) cluster analysis of an IR spectra data set and displays the results of CLA as images and/or as dendrograms. First, it calculate distance matrix, which contains information on the similarity of spectra. Then, in hierarchical clustering, the algorithm searches within the distance matrix for the two most similar IR spectra (minimal distance). These spectra are combined into a new object (called a "cluster" or called "hierarchical group"). The spectral distances between all remaining spectra and the new cluster are re-calculated ${ }^{[53]}$. For cluster analysis, Ward's algorithm was used in our studies for clustering. Spectral distances were computed as D-values. In a dendrogram, spectral distances were given on the $\mathrm{Y}$-axis. Horizontal lines illustrated the merging process, eg the combination of two clusters to a new cluster of spectra. It is a technique which clusters IR spectra based on similarity with other spectra. This method can give results with a better discrimination of different feed structures using feed chemical image ${ }^{[59]}$ and group spectrum ${ }^{[60]}$.

The report shows that the clusters in the pericarp region, aleurone layer and endosperm region are different between plants and between plant structures within the plant. From the CLA diagram, three classes can be distinguished below a linkage distance less than 23, with $C_{-} E$ group forming a separate group. Depending on the aggregation level (horizontal axis) different explanations can be inferred. The C_P group and B_E group form the two distinct groups just below an aggregation (linkage) distance 8 . They form a single group at an aggregation distance of about 22. The C_E group can be grouped together with the C_P and B_E groups for a linkage distance equal to about 38. The results clearly show significantly different spectral clusters in the different plant seed structures: pericarp region, aleurone layer and endosperm region using whole spectral region from 4000 to $800 \mathrm{~cm}^{-1}$ for CLA analysis. In other words, different feed structures have different spectra clusters and different feeds have different spectra clusters.

Principal Component Analysis to Identify Plant Intrinsic Structural Differences: The second multivariate analysis, is PCA analysis which is a statistical data reduction method. It transforms the original set of variables to a new set of uncorrelated variables called principal components (PCs). The first few PCs will typically account for $>95 \%$ variance. The purpose of PCA analysis is to derive a small number of independent linear combinations (PCs) of a set of variables that retain as much of the information in the original variables as possible. This analysis allows studying globally the relationships between $p$ quantitative characters (eg. feed chemical functional groups) observed on $n$ samples (eg FTIR spectra of 
plants and plant structural regions). The basic idea is to extract, in a multiple variable system, one, two or sometimes more PCs that carry maximum information. These components are independent (orthogonal) of each other and the first factor generally represents maximum variance. As factors are extracted, they account for less and less variability and the decision of when to stop basically depends on the point when there is only very little significant variability left, or merely random noise. Thus, reduction of data provides a new coordinate system where axes (eigenvectors) represent the characteristic structure information of the data and the spectra may then be simply described as function of specific properties, and no longer as a function of intensities. The outcome of such an analysis can be presented either as a 2D (two PCs) or 3D (three PCs) scatter plots [61]. The PCA analysis have been applied in tissue ultra-structural chemistry research to detect the structural-chemical difference and effect of heat processing $[10,55,60]$.

Novel Applications of Synchrotron-Based FTIR Microspectroscopy in Protein Structure Research

Determination of the Internal Protein Secondary Structure Changes ( $\alpha$-Helix and $\beta$-Sheet and their ratios) of Raw and Heat Treated Brown and Golden Flaxseeds and Relation to Nutritive Value of Protein: The objectives of the study [10] were to use the S-FTIRM to: 1) reveal ultra-structural chemical features of protein secondary structures of flaxseed tissues affected by varieties (brown and golden) and heating processing (raw and roasting) within intact tissues at a cellular level, in relation to protein nutritive value, utilization and availability and 2) quantify protein secondary structures using Gaussian and Lorentzian methods of multi-component peak modeling. The experiment was performed at the National Synchrotron Light Source (NSLS) in Brookhaven National Laboratory (BNL, US Dept of Energy, New York).

This study [10] showed that with the SFTIRM, the structural-chemical makeup of the flaxseed tissues could be revealed at ultra-spatial resolution within cellular dimensions. The protein secondary structure differed between the golden and brown flaxseed tissues in terms of proportions and ratios of $\alpha$ helix and $\beta$-sheet. By using multi-component peaks modeling at protein amide I region of $1700-1620 \mathrm{~cm}^{-1}$, the results show that the golden contained relatively higher proportions of model-fitted $\alpha$-helix (47 vs. 37\%), lower proportion of model-fitted $\beta$-sheet (37 vs. 46\%) and higher ratio of $\alpha$-helix to $\beta$-sheet (1.3 vs. 0.8 ), indicating potential high protein value, high nutrient utilization and availability in the golden flaxseeds.

The roasting reduced proportions of $\alpha$-helix (from 47 to 36 ), increased proportions of $\beta$-sheet (from 37 to $50 \%$ ) and reduced $\alpha$-helix to $\beta$-sheet ratio (1.3 to 0.7) of the golden flaxseed tissues. However, the roasting did not affect percentage and ratio of $\alpha$-helix and $\beta$-sheet in the brown flaxseed tissue. These results indicated different sensitivities of protein secondary structure to the heat processing between the flaxseed varieties and that the roasting may affect protein value, nutrient utilization and availability in the golden seeds but not in the brown.

In this study [10], multivariate statistical analyses were also used to discriminate and classify inherent protein structures of the raw and roasted brown and golden flaxseed tissues. Although the cluster analysis [60] showed that the four flaxseed (F1 to F4) cannot be fully distinguished, however, when combined brown and golden flaxseed together and emphasized on the raw and roasting effects, the PCA analysis [60] could almost fully distinguish between the raw and roasted flaxseeds in protein amide I FSD spectrum at the region of $1700-1620 \mathrm{~cm}^{-1}$ and the raw and roasted can be grouped in separate ellipses. The first three PCs explain $36.7,19.4$, and $16.5 \%$ of the variations in the protein amide FSD spectrum data set.

These results demonstrate the potential of highly spatially resolved synchrotron FTIR microspectroscopy to localize relatively "pure" protein body in the tissues and reveal protein secondary structures at a cellular level without destruction of the inherent structure of the tissue and eliminate other components such as carbohydrate scattering effect on the protein spectrum. The results indicated relative differences in protein secondary structures between flaxseed varieties and differences in sensitivities of protein secondary structure to the heat processing. The further study is needed to quantify the relationship between protein secondary structures and protein nutrient availability of various varieties of flaxseeds and to answer a question whether the changes in the relative amounts of protein secondary structures are primarily responsible for differences in protein availability or utilization or at what magnitudes of changes result in substantially nutritive value changes.

Identification of the Structural Chemical Differences in the Protein Matrix of Endosperm Tissues between Harrington (Malting-type) and Valier (Feed-type) Barley in Relation to 
Biodegradation Characteristics: Harrington is a malting-type barley variety. As with most barley varieties, its extent and rate of biodegradation in the rumen are high ${ }^{[62]}$. However, if ruminants consume rapidly degradable barley, the incidence of digestive disorders such as bloat and acidosis can increase. This reduces animal performance and can lead to death in acute cases ${ }^{[63,64]}$. Valier barley has been recently developed as a specialized feed barley for ruminants ${ }^{[65}$, ${ }^{66]}$. Its extent and rate of rumen degradation are low, which should be beneficial to animal performance and health when animals are fed this variety ${ }_{[62]}$.

The hypothesis for this study ${ }^{[23]}$ was that the different degradation characteristics between the two barley varieties may be partly due to differences in the protein-starch matrix of the endosperm tissue. As we know, traditional "wet" chemical analysis cannot detect such biological differences because the inherent seed structures that may inhibit digestion are destroyed during processing for analysis. "Wet" chemical analysis also showed that the total chemical composition were similar between the two barleys ${ }^{[62]}$.

The objective of this study ${ }^{[23]}$ was to use the S-FTIRM to identify differences in the structural makeup of Harrington and Valier barley endosperm tissues, so as to obtain a better understanding of the intrinsic structure of barley endosperm tissue in relation to rumen degradation characteristics. The experiment was performed at the beamline Port 031 in Synchrotron Radiation Center (SRC, University of Wisconsin). The photomicrograph of cross-sections of the endosperm tissue of Harrington and Valier barley ${ }^{[23]}$ showed that Harrington has larger starch granules that are less densely packed in the protein matrix, relative to Valier. As with traditional analytical methods, it is difficult to pinpoint exact differences. No specific chemical information on barley micro-endosperm tissue is obtained through such images. Using the synchrotron based analytical technique- S-FTIRM technique, the results showed that Harrington had a wider range of starch to protein IR absorbance intensity ratio (1.406 to 10.119 vs. 1.419 to 4.274 ), suggesting that it is more heterogeneous than Valier in endosperm chemical makeup. Valier had a lower ratio of starch to protein IR absorbance intensity than Harrington (4.121 \pm 0.576 vs. $2.776 \pm 0.270$ ), which implies that the starch granules in Valier are more closely associated with the protein matrix. This closer association may prevent the starch granules from being rapidly degraded in the rumen.

The lower starch to protein ratio in the microendosperm tissue of Valier barley may provide a clue to reduced effective degradability and the somewhat slower rate of rumen nutrient degradation observed in the in situ study ${ }^{[62]}$ (Yu et al. 2003c). McAllister et al. ${ }^{[22]}$, for example, suggested that the protein matrix surrounding starch granules is a major factor responsible for differences in the rate of ruminal starch digestion of cereal grains. Efficient starch digestion by ruminal microorganisms requires an array of fiberolytic, proteolytic and amylolytic enzymes. The extent to which protein and structural carbohydrates shield underlying starch granules from enzymatic attack differs among cereal grains ${ }^{[67]}$. The greater association of the protein matrix with the starch granules in the endosperm tissue of Valier barley may limit access of ruminal microorganisms to the starch granules and thus reduce the rate and extent of degradation relative to that of Harrington barley. This study ${ }^{[23]}$ indicated that Harrington and Valier barley differ in chemical/structural endosperm matrix makeup. The lower ratio of starch to protein SR-FTIR absorbance intensity for Valier indicated a tighter association between starch and protein in the endosperm. This may explain why Valier exhibits a lower extent and rate of rumen degradation than Harrington barley.

Detecting Chemical Make-up Differences of Protein Structures between Yellow- (Brassica Rapa) and Brown-Seeded (Brassica Napus) Canola: Traditionally, when we determine protein value, we usually determine total protein content. According to total protein content, higher or lower, in comparison to a standard, we determine the protein value. This approach has been used for a long time. However, this approach has a significant disadvantage. This is because protein value relies on not only total protein content, but also protein inherent structures ${ }^{[14,21,23,68]}$ and nutrient matrix ${ }^{[23]}$. The inherent protein structures affect the protein access to gastrointestinal digestive enzyme. The nutritive value, digestibility and availability of protein do not directly depend on $\alpha$-helix and $\beta$-sheet, but the types of protein and their specific susceptibility to enzymatic hydrolysis (inhibitory activities) in the gastrointestines are highly associated with protein inherent structures. High $\beta$-sheet to $\alpha$-helix ratio may result in low access to intestinal digestive enzymes, resulting in low protein value. Even if tissue contain the same protein content, their nutritive value may be different if their $\alpha$-helix and $\beta$-sheet ratios in the protein secondary structures are different.

Canola is oil seeds and its protein content also high, therefore, considered as an important protein source. Canola seeds in Canada, like soybean, are often used to extract purified protein source as a replacement 
for fish meal or as a low rumen undegradable protein source, called "Fiber Protein". Usually, Canola contains yellow- and brown-seeded varieties. In western Canada, Brassica canola including the yellow-seeded Brassica rapa and dark-brown seeded Brassica napus varieties are commonly grown. No study has been found to determine differences of inherent protein structures between the yellow- and brown-seeded Brassica canola varieties.

The objective of this study was to use the SFTIRM to identify the molecular structural differences of protein between the yellow- vs. brown-seeded Brassica canola. The study showed that with the SFTIRM, the molecular chemistry and the structuralchemical makeup and characteristics were revealed and identified between two varieties of canola seeds. Compared the yellow- and browned-seeded canola tissues, amount and percentage of protein amide I FSD multi-component (5-8 peaks) peaks between the two varieties of canola seeds was significantly different. In the yellow-seeded canola tissue, $10 \%$ protein amide I FSD spectrum was with 5 peak bands, $17 \%$ was with 6 peak bands, $5 \%$ was 7 peaks bands and no 8 peaks band spectrum was found in the yellow-seed canola variety. However, in the brown-seeded canola tissue, no 5 peak band spectrum was found, $35 \%$ was with 6 peak bands, $55 \%$ was with 7 peak bands and $10 \%$ was 8 peaks bands. The average peaks in protein amide I region for the yellow-seeded canola tissue was 6 and average peaks for the brown-seeded canola was $7(\mathrm{SEM}=0.1)$. These results showed a difference in protein structures between the yellow- and browned-seeded canola tissues. It needs to be mentioned that the distinction between $5,6,7$, and 8 peaks may appear to be due to the number of components between around 1560 and $1610 \mathrm{~cm}^{-1}$, this region might be not strictly amide I and could be influenced by other components.

Compared the yellow- and browned-seeded canola tissues, the yellow-seeded canola contained lower percentage of $\alpha$-helix (33 vs. 37), higher percentage of $\beta$-sheet (27 vs. $21 \%$ ) and lower ratio of $\alpha$ helix to $\beta$-sheet (1.3 vs. 1.9). These results indicated that protein quality of the yellow-seeded canola may be lower than that of the browned-seeded canola tissues because of higher ratio of $\beta$-sheet to $\alpha$-helix in protein secondary structure, which usually cause lower access of protein to gastrointestinal digestive enzymes, thus resulting in lower protein value. No report has been found in the literature to indicate protein secondary structure in canola seed tissues. However, the CLA and PCA analysis did not show distinguished differences between the yellow- and brown-seeded canola tissues in protein amide I structures, indicating they are related each other. Both yellow- and brown-seeded canola contain the same proteins in different ratios.

In conclusion, this study showed that the yellow-seeded canola contains lower percentage of $\alpha$ helix, higher percentage of $\beta$-sheet and lower ratio of $\alpha$ helix to $\beta$-sheet in protein secondary structure, which may indicate lower value and quality of protein than the brown-seed canola. However, CLA and PCA analysis did not show completed difference between the yellowand brown-seeded canola tissues in protein amide I structures, indicating they are related each other. Both yellow- and brown-seeded canola contain the same proteins in just different ratios. More detailed and systematical study is required to define the extent of differences that exist between the yellow- (Brassica rapa) vs. brown-(Brassica napus) seeded canola, not only differences in inherent protein structures but also the difference in the distribution, in associated with nutritive values. This novel approach will provide important information for canola breeding, animal feed and human food industries to maintain and improve high quality of protein in Canola seeds.

\section{STUDY PROTEIN SUBFRACTIONS AFFECTED BY HEAT PROCESSING IN RELATION TO BIODEGRADATION CHARACTERISTICS USING THE CNCPS SYSTEM}

To detect features and characteristics of rumen degradation of protein, another method is to use the CNCPS system [16] to partition protein fractions. According to protein subfractions, we are able to predict the rumen degradation behavior of proteins. When proteins are treated physically, chemically and biologically (eg heat processing), the protein fraction profiles are also changed. With the CNCPS system, it is able to detect and identify such structural changes in relation to protein rumen degradation characteristics and utilization on the quantitative base.

Principle of Partitioning Protein Fractions: The protein fraction can be partitioned according to the CNCPS system ${ }^{[16]}$. The characterizations of the $\mathrm{CP}$ fractions as applied in this system are as follows: Fraction $\mathrm{PA}$ is non-protein $\mathrm{N}$, fraction $\mathrm{PB}$ is true protein, and fraction $\mathrm{PC}$ is unavailable protein. Fraction PB is further divided into three fractions (PB1, PB2, and PB3) that are believed to have different rates of degradation in the rumen. Buffer-insoluble protein minus fraction $\mathrm{PB} 3$ is used to estimate fraction $\mathrm{PB} 2$. Fraction PB2 is insoluble in buffer but soluble in 
neutral detergent, while fraction PB3 is insoluble in both buffer and neutral detergent, but is soluble in acid detergent.

Fraction PB2 is fermented in the rumen at a lower rate than buffer-soluble fractions, and some of the PB2 fraction escapes to the lower gut. Fraction PB3 is believed to be more slowly degraded in the rumen than fractions PB1 and PB2 because of its association with the plant cell wall; a large proportion of PB3 is thus believed to escape the rumen. Fraction PC is the acid detergent insoluble $\mathrm{N}$, which is highly resistant to breakdown by microbial and mammalian enzymes, and it is assumed to be unavailable for the animal ${ }^{[16]}$. The relative rumen degradation rates of the five protein fractions have been described by Sniffen et al. ${ }^{[16]}$ as follows: Fractions PA is assumed to be infinity, fraction PB1 is $1.20-4.00 / \mathrm{h}$, fraction PB2 is $0.03-0.16 / \mathrm{h}$, fraction PB3 is $0.0006-0.0055 / \mathrm{h}$. Fraction $\mathrm{PC}$ is considered to be undegradable.

In models designed to assess utilization of protein by ruminants, it is assumed that most of the soluble protein (PA and $\mathrm{PB} 1$ ) is completely and fast degraded in the rumen and varying proportions of the insoluble fractions (PB2, PB3, and PC) escape ruminal degradation depending on the interactive effects of digestion and passage ${ }^{[16]}$. Because various protein fractions differ in rate and extent of ruminal degradation, the proportions of these different protein fractions are believed to influence the amounts of ruminally degraded and escape protein consumed by animals ${ }^{[69]}$.

\section{APPLICATIONS OF PARTITIONING PROTEIN FRACTIONS IN PROTEIN STRUCTURAL RESEARCH}

Effect of Roasting on Protein Subfractions of Brown and Yellow Flaxseed and Relation to Biodegradation Behavior: In the recent studies ${ }^{[10,12]}$, the S-FTIRM was used as a novel approach to reveal molecular chemistry of protein in the seed tissues affected by roasting and variety (brown and yellow) and relatively estimate protein structures, in relation to rumen protein digestive behaviors and nutritive value, estimated using the CNCPS system ${ }^{[16]}$. The study ${ }^{[10,12]}$ showed that the S-FTIRM revealed that the secondary structure of protein differed between the raw and roasted golden flaxseeds in terms of the proportions and ratios of $\alpha$ helix and $\beta$-sheet within cellular dimensions. The roasting reduced percentage of model-fitted $\alpha$-helix, increased percentage of model-fitted $\beta$-sheet and reduced $\alpha$-helix to $\beta$-sheet ratio in the golden flaxseeds, which indicated that a negative effect of the roasting on protein values, utilization and availability. These results were proved by the CNCPS system which also revealed that the roasting increased protein bound to lignin, and Maillard reaction protein, which are poorly used by the ruminants and increased indigestible and undegradable protein. Comparing the raw and the roasted, the raw was higher in PA (43 vs. $21 \mathrm{~g} / \mathrm{kg} \mathrm{DM}$ ) and PB1 (255 vs. $64 \mathrm{~g} / \mathrm{kg} \mathrm{DM}$ ), but lower in PB2 (41 vs. $243 \mathrm{~g} / \mathrm{kg} \mathrm{DM}$ ), PB3 (41 vs. $243 \mathrm{~g} / \mathrm{kg} \mathrm{DM}$ ) and PC (12 vs. $16 \mathrm{~g} / \mathrm{kg} \mathrm{DM})$, indicating large and potential differences in rumen protein degradation characteristics between the raw and the roasted golden flaxseed. Higher PA and PB1 content in the raw indicated that roasting processing reduced soluble protein $(\mathrm{PA}+\mathrm{PB} 1)$ which are fast degraded in the rumen. Lower PB2 and PB3 fractions associated with the cell wall in the raw indicated that the roasting processing increased slowly degradable and intermediately degradable proportions. Fraction PC consists of protein bound to lignin and Maillard reaction protein. From the nutritive point of view, this fraction appears to be essentially indigestible and the amount apparently digested is poorly used by animals $[16,70,71]$. In this study, the roasted flaxseed had a higher PC fraction than the raw flaxseed, which indicated that the roasting increased undegradable and undigestive protein fractions, which may be an indication of overprocessing and reduction of protein nutritive value.

Effect of Barely Variety (Harrington and Valier) and Processing Methods (Coarse and Fine) on Protein Subfractions in Relation to Biodegradation Kinetics : The objectives of this study ${ }^{[62]}$ were to compare protein and carbohydrate fractions, digestive behavior between malting-type barley (cv. Harrington) and feed-type barley (cv. Valier), which were affected by coarse (Roller miller, $0.533 \mathrm{~mm}$ gap) and fine (Hammer mill, $2 \mathrm{~mm}$ screen) processings using the CNCPS protein fraction system. The study showed that the true protein fractions (PB1, PB2, PB3) between Harrington and Valier barley were similar. However, the PA and PC fractions were higher in Harrington barley. The results indicated that Harrington barley had a greater rapidly degradable fraction of NPN, and a higher undegradable PC fraction associated with the cell wall than Valier barley. Carbohydrate fractions were different between the two varieties. Valier barley was lower in rapidly degradable $\mathrm{CHO}$ (CA: 86 vs. 188 $\mathrm{g} / \mathrm{kg} \mathrm{CHO}$ ) and CB2 (202 vs. $231 \mathrm{~g} / \mathrm{kg} \mathrm{CHO}$ ), higher in intermediately degradable $\mathrm{CHO}$ (CB1: 652 vs. $548 \mathrm{~g} / \mathrm{kg}$ $\mathrm{CHO}$ ) and unavailable $\mathrm{CHO}$ (CC: 60 vs. $34 \mathrm{~g} / \mathrm{kg} \mathrm{CHO}$ ). These results indicated that Valier barley contained 
lower amounts of rapidly degradable soluble sugars, a higher intermediately degradable fraction (such as pectin), a lower slowly degradable fraction associated with the plant cell wall but available depending on the rate of rumen turnover, and a higher undegradable cell wall. Using the coarse processing, Valier barley was lower in rumen degradability of DM (472 vs. $631 \mathrm{~g} / \mathrm{kg}$ ) and CP (459 vs. $617 \mathrm{~g} / \mathrm{kg}$ ), but not different in rumen degradability of starch (average $619 \mathrm{~g} / \mathrm{kg}$ ). However, using the fine processing, the significant differences on rumen degradation characteristics completely disappeared between two barley varieties except of degradation rate of CP. In conclusion, Valier barley had different chemical and nutritional characterization compared with Harrington barley. However, the nutritional characterization (in terms of rumen digestive behaviors and potential nutrient supply) was highly associated with the processing methods.

We also used the S-FTIRM to study inherent barley endosperm structure and found that, as mentioned before, the greater association of the protein matrix with the starch granules in the endosperm tissue of Valier barley might be a reason to limit access of ruminal microorganisms to the starch granules and thus reduce the rate and extent of degradation relative to that of Harrington barley. This study may explain why Valier exhibits a lower extent and rate of rumen degradation than Harrington barley.

\section{MODELING PROTEIN AVAILABILITY AFFECTED BY HEAT TREATMENTS, USING THE DVE/OEB SYSTEM AND THE NRC-2001 MODEL}

Background of Modeling Protein Availability/Supply: Most mammals can only metabolize dietary protein as amino acids or peptides absorbed from the small intestine. In ruminants, the relationship is somewhat more complicated. They required not only $\mathrm{N}$ available for rumen microbial protein synthesis, but also digestible dietary protein bypassing the rumen $[7,17,18]$. Several sophisticated models exist to quantitatively predict protein nutrient supply and availability to dairy cows, both in the rumen and intestines. Modern protein evaluation systems, the DVE/OEB system ${ }^{[17,18]}$ and the NRC-2001 model ${ }^{[19]}$, have been developed based on principles in the existing models or protein evaluation systems, such as PDI ${ }^{[72,}$ ${ }^{73]}$, ARC ${ }^{[74]}$, NJK-NJF ${ }^{[75]}$, AAT-PVB ${ }^{[76]}$, AP ${ }^{[77]}$, ADPLS and MF ${ }^{[78]}$. These two models consider the strong elements of other developed protein evaluation systems and they also introduce new elements, such as the role of energy balance in intestinal protein supply.

In the DVE/OEB system ${ }^{[18]}$, the protein value for feeds and the requirements for dairy cows are both expressed as the amount of protein (microbial and feed source) truly digested in and absorbed from the small intestine of the animal. This system can give information on the quantitative aspects of both ruminal and post-ruminal protein digestion in ruminants. In the DVE/OEB system, each feed has a DVE value, which stands for true absorbable protein in the small intestine, composed of: 1) digestible feed true protein escaping rumen degradation, 2) digestible true microbial protein synthesized in the rumen, and 3) a correction for endogenous protein losses in the digestive tract. In this system [18], each feed also has a rumen degraded protein balance value, called "OEB", which shows the balance or imbalance between microbial protein synthesis potentially possible from available rumen degradable protein and that potentially possible from the energy extracted during anaerobic fermentation in the rumen. When OEB is positive, it indicates the potential loss of $\mathrm{N}$ from the rumen. When negative, microbial protein synthesis may be impaired because of a shortage of $\mathrm{N}$ in the rumen. The optimum $\mathrm{OEB}$ value in a ration is therefore zero or slightly above ${ }^{[18]}$.

The NRC-2001 model [19] introduced the concepts of metabolizable protein (MP), defined as true protein that is digested and absorbed by the intestine, and contributed by 1) ruminally undegraded feed protein, 2) ruminally synthesized microbial protein, and 3 ) endogenous protein from rumen. Based on the data from NRC model ${ }^{[19]}$, the rumen degraded protein balance (DPB) can also be calculated and it reflects the difference between the potential microbial protein synthesis based on ruminally degraded feed protein and that based on total digestible nutrients (TDN) as energy available for microbial fermentation in the rumen.

\section{PRINCIPLES AND METHODOLOGY OF MODELING PROTEIN SUPPLY}

The Concepts of the DVE/OEB System: The detailed concepts and formulas of the DVE/OEB system are provided by Tamminga et al. ${ }^{[18]}$. The following is a brief explanation in order to understand how to calculate and predict protein supply to the small intestine of dairy cows as a result of feeding protein feeds affected by the heat processing.

Calculation of FOM and RUP ${ }^{\text {DEV }}$ : Ruminally undegraded feed protein $\left(\mathrm{RUP}^{\mathrm{DEV}}\right)$ in the DVE/OEB 
system was calculated as: $\mathrm{RUP}^{\mathrm{DEV}}=1.11 \times \mathrm{CP} \times \% \mathrm{RUP}$, where, $\% R U P=U+D \times K p /(K p+K d)$, the passage rate $(\mathrm{Kp})$ of $6 \% / \mathrm{h}$ was adopted ${ }^{[18]}$. The factor 1.11 is taken from the French PDI-system ${ }^{[73]}$. This represents the regression coefficient of in vivo on in situ degradation data.

The content of organic matter fermented in the rumen (FOM) was estimated from digestible organic matter subtracted ether extract, RUP ${ }^{\mathrm{DEV}}$, ruminally undegraded feed starch and fermentation products (assumed to be zero for concentrate feedstuffs), or the FOM is estimated as: $\mathrm{FOM}=\mathrm{OM} \times \% \mathrm{RUOM}^{[79]}$.

Microbial Protein Synthesis in the Rumen: Microbial protein synthesized in the rumen $\left(\mathrm{MCP}_{\mathrm{FOM}}\right)$ was estimated as $15 \%$ of the rumen fermented organic matter $(\mathrm{FOM})\left[\mathrm{MCP}_{\mathrm{FOM}}=0.15 \times \mathrm{FOM}\right]$. The factor 0.15 means that per $\mathrm{kg}$ FOM, $150 \mathrm{~g}$ of microbial protein $\mathrm{CP}$ is assumed to be synthesized ${ }^{[18]}$.

Of the microbial protein, $75 \%$ was added to the undegraded feed protein (RUP ${ }^{\mathrm{DEV}}$ ) to estimate the true protein supplied to the small intestine (TPSI) [TPSI=RUP $\left.{ }^{\mathrm{DEV}}+0.75 \times \mathrm{MCP}_{\mathrm{FOM}}\right]$. The factor 0.75 means that $75 \%$ of microbial $\mathrm{N}$ is present in amino acids. The remaining $25 \%$ represented $\mathrm{N}$ in nucleic acids.

Intestinal Digestion of Feed and Microbial protein: The previously discussed RUP ${ }^{\mathrm{DEV}}$ and TPSI must be corrected for incomplete digestion and endogenous secretions ${ }^{[18]}$. A correction is needed for protein losses due to incomplete digestion and from endogenous secretions. True digestibility of microbial protein is assumed to be $85 \%{ }^{[80]}$ and therefore the amount of truly absorbed rumen synthesized microbial protein in the small intestine $\left(\mathrm{AMCP}^{\mathrm{DVE}}\right)$ was estimated as: $\mathrm{AMCP}^{\mathrm{DVE}}=0.85 \times 0.75 \times \mathrm{MCP}_{\mathrm{FOM}}$.

For feed ingredients, the content of truly absorbed bypass feed protein in the small intestine $\left(\mathrm{ARUP}^{\mathrm{DVE}}\right)$ was calculated as: $A R U P^{\mathrm{DVE}}=\% \mathrm{dRUP} \times \mathrm{RUP}^{\mathrm{DVE}}$, or calculated as: ARUP $^{\text {DVE }}=$ RUP $^{\text {DVE }}-U C P$, where, the amount of potential undigested $\mathrm{CP}$ (UCP) is calculated as: $\mathrm{UCP}=\mathrm{CP} \times \% \mathrm{U}_{\mathrm{CP}}$, where, $\% \mathrm{U}_{\mathrm{CP}}$ was protein residue remaining after a longer-term in situ incubation of 336 $\mathrm{h}$. It was assumed that undegradable $\mathrm{CP}$ after a 336-h incubation is indigestible in the small intestine ${ }^{[18,79]}$. In some experiment, $\% \mathrm{U}_{\mathrm{CP}}$ could be determined following a $72 \mathrm{~h}$ in situ incubation as long as further incubation from 72 to $336 \mathrm{~h}$ resulted in no further digestion in some feedstuffs.

Endogenous Protein Losses in the Small Intestine: Endogenous protein losses in the digestive tract
(ENDP) are related to the amount of undigested DM (UDM) excreted in the faeces. According to the DVE/OEB system, $75 \mathrm{~g}$ of absorbed protein per $\mathrm{kg}$ UDM in fecal excretion is required to compensate for the endogenous losses. Therefore ENDP was calculated as: $\mathrm{ENDP}=0.075 \times \mathrm{UDM}$, where, UDM was calculated as undigested organic matter (UOM) plus undigested ash (UASH) [UDM=UOM+UASH, where, $\mathrm{UOM}=\mathrm{OM} \times \% \mathrm{U}_{\text {om }}, \% \mathrm{U}_{\text {om }}$ was residue of feed $\mathrm{OM}$ following an in situ incubation of $72 \mathrm{~h}$, and $\mathrm{UASH}=\mathrm{ASH} \times 35 \%[81]$.

Truly Digested and Absorbed Protein in the Small Intestine: Truly digested and absorbed protein in the small intestine (DVE value) are contributed by 1) feed protein escaping rumen degradation (RUP $\left.{ }^{\mathrm{DVE}}\right), 2$ ) microbial protein synthesized in the rumen $\left(\mathrm{MCP}_{\mathrm{FOM}}\right)$, and 3) a correction for endogenous protein losses in the digestive tract (ENDP). Therefore the DVE value was estimated as: $\mathrm{DVE}=\mathrm{ARUP}{ }^{\mathrm{DVE}}+\mathrm{AMCP}^{\mathrm{DVE}}-\mathrm{ENDP}$.

Degraded Protein Balance: The degraded protein balance $\left(\mathrm{DPB}^{\mathrm{OEB}}\right)$ is the balance between microbial protein synthesis from rumen degradable protein and that from the energy extracted during anaerobic fermentation in the rumen. Therefore the $\mathrm{DPB}^{\mathrm{OEB}}$ value was estimated as: $\mathrm{MCP}_{\mathrm{RDP}}{ }^{\mathrm{DVE}}-\mathrm{MCP}_{\mathrm{FOM}}$, where, $\mathrm{MCP}_{\mathrm{RDP}}{ }^{\mathrm{DVE}}=\mathrm{CP}-1.11 \times \mathrm{RUP}$. When the degraded protein balance is positive, it indicates the potential loss of $\mathrm{N}$ from the rumen. When negative, microbial protein synthesis may be impaired, because of a shortage of $\mathrm{N}$ in the rumen. The optimum value of the degraded protein balance in a ration is therefore zero or slightly above ${ }^{[18]}$.

The Concept of the NRC-2001 Model: The detailed concepts and formulas are provided by NRC ${ }^{[19]}$. A brief explanation is as follows:

Calculation of RDP ${ }^{\mathrm{NRC}}$ and RUP ${ }^{\mathrm{NRC}:}$ Using the NRC2001 model, ruminally undegraded feed protein was calculated as: $\mathrm{RUP}^{\mathrm{NRC}}=\mathrm{CP} \times \% \mathrm{RUP}$. Ruminally degraded feed protein was calculated as: $\mathrm{RDP}^{\mathrm{NRC}}=\mathrm{CP} \times \% \mathrm{RDP}$, where, $\mathrm{RDP}$ was calculated as: $\% R D P=S+D \times K d /(K p+K d)$, where, $K p$ of 6 and $4 \% / h$ were adopted for concentrate and forage feeds, respectively.

Rumen Microbial Protein Synthesis: Ruminally synthesized microbial protein was calculated as: $\mathrm{MCP}^{\mathrm{NRC}}=0.13 \times \mathrm{TDN}$, when $\mathrm{RDP}^{\mathrm{NRC}}$ exceeded $1.18 \times \mathrm{TDN}$-predicted MCP $\left(\mathrm{MCP}_{\mathrm{TDN}}\right)$. When $\mathrm{RDP}^{\mathrm{NRC}}$ 
was less than $1.18 \times \mathrm{TDN}$-predicted $\mathrm{MCP}\left(\mathrm{MCP}_{\mathrm{TDN}}\right)$, then $\mathrm{MCP}^{\mathrm{NRC}}$ was calculated as 0.85 of $\mathrm{RDP}^{\mathrm{NRC}}$ $\left(\mathrm{MCP}_{\mathrm{RDP}}\right)$. The factor 0.13 means that per kg TDN, 130 $\mathrm{g}$ of microbial protein CP is assumed to be synthesized.

Intestinal Digestion of Feed and Microbial Protein: Digestibility and true protein of ruminally synthesized microbial protein are assumed to be $80 \%$, therefore the amount of truly absorbed $\mathrm{MCP}^{\mathrm{NRC}}$ was estimated as: $\mathrm{AMCP}^{\mathrm{NRC}}=0.80 \times 0.80 \times \mathrm{MCP}^{\mathrm{NRC}}$.

For feed ingredients, truly absorbed rumen undegraded feed protein in the small intestine $\left(\mathrm{ARUP}^{\mathrm{NRC}}\right.$ ) was calculated as: $\mathrm{ARUP}^{\mathrm{NRC}}=\mathrm{dRUP} \times \mathrm{RUP}^{\mathrm{NRC}}$, or calculated as: $A R U P^{N R C}=R^{N} P^{N R C}-U C P$, where, $\mathrm{UCP}=$ the amount of potential undigested $\mathrm{CP}$ estimated by in situ work, calculated as: $\mathrm{CP} \times \% \mathrm{U}_{\mathrm{CP}}$.

Rumen endogenous protein in the small intestine: Rumen endogenous $\mathrm{CP}$ was calculated as: $\mathrm{ECP}=6.25 \times 1.9 \times \mathrm{DM} / 1000$ (where, $\mathrm{DM}$ in $\mathrm{g} / \mathrm{kg}$ ) Assuming that $50 \%$ of rumen endogenous $\mathrm{CP}$ passes to the duodenum and $80 \%$ of rumen endogenous $\mathrm{CP}$ is true protein [19], therefore the truly absorbed endogenous protein in the small intestine (AECP) was estimated as: $\mathrm{AECP}=0.50 \times 0.80 \times \mathrm{ECP}$.

Total Metabolizable Protein: Total metabolizable protein is contributed by 1) digestible $\mathrm{RUP}^{\mathrm{NRC}}, 2$ ) digestible $\mathrm{MCP}^{\mathrm{NRC}}$, and 3) $\mathrm{ECP}$, calculated as: $\mathrm{MP}=\mathrm{ARUP}^{\mathrm{NRC}}+\mathrm{AMCP}^{\mathrm{NRC}}+\mathrm{AECP}$.

Degraded Protein Balance: Based on the data from the NRC dairy model ${ }^{[19]}$, the degraded protein balance $\left(\mathrm{DPB}^{\mathrm{NRC}}\right)$ can be calculated. It reflects the difference between the potential microbial protein synthesis based on ruminally degraded feed crude protein $\left(\mathrm{RDP}^{\mathrm{NRC}}\right)$ and that based on 1.18 times of energy (TDN) available for microbial fermentation in the rumen, calculated as: $\mathrm{DPB}^{\mathrm{NRC}}=\mathrm{RDP}^{\mathrm{NRC}}-1.18 \mathrm{MCP}_{\mathrm{TDN}}$.

\section{COMPARISON OF THE NRC-2001 MODEL WITH THE DVE/OEB SYSTEM IN THE PREDICTION OF PROTEIN AVAILABILITY AND SUPPLY}

Comparison of Predictions of Nutrient Supply to Dairy Cows between the Two Models: The studies ${ }^{[82]}$ did comparison of the DVE/OEB system and the NRC2001 model in the prediction of potential protein supply to dairy cows from concentrates, which showed that the predicted values from the DVE/OEB system and the
NRC-2001 model had significant correlations. Using the DVE/OEB system, the mean supply of microbial protein based on available energy and total absorbed protein in the small intestine were lower by 9.4 and $12.9 \mathrm{~g} / \mathrm{kg}$ DM, respectively. However, the mean supply of microbial protein based on ruminally degraded protein and the degraded protein balance value were higher by 21.6 and $17.4 \mathrm{~g} / \mathrm{kg} \mathrm{DM}$, respectively, in comparison to that predicted by the NRC-2001 model for the concentrate feedstuffs. In this study [82], using the DVE/OEB system, the overall average microbial protein supply based on available energy from rumen fermented OM was 10\% lower, microbial protein supply based on ruminally degraded feed protein was $10 \%$ higher, and the truly absorbed protein in the small intestine was $8 \%$ lower than that predicted by the NRC2001 model. However, the correlation of the predicted values from the two models were high $(\mathrm{R}>0.90)$ except of potential microbial protein supply based on energy. The most important outputs (net results), the DVE in the DVE/OEB system vs. the MP in the NRC-2001 model, were $9.7 \mathrm{~g} / \mathrm{kg}$ DM difference on average. The relationship of the predicted protein values between the DVE/OEB system and the NRC-2001 model were reported.

Differences between the NRC-2001 Model and DVE/OEB System: Input data generated by the both models (the DVE/OEB system and NRC-2001 model), though of significance in the dairy cows, are best regarded as characteristics of the test feed materials. These two models consider the strong elements of other recently developed protein evaluation systems and they also introduce new elements. Although the principles of these two models are similar, some of the factors used in quantifying calculations and some concepts differ [82].

Differences in Prediction of Endogenous Protein: Both models consider endogenous protein, however, the concepts and definitions are different. In the DVE/OEB system ${ }^{[18]}$, calculation of the DVE value requires a correction for endogenous protein losses in the small intestine, which are affected by undigested DM. According to the DVE/OEB system, $75 \mathrm{~g}$ of absorbed protein per $\mathrm{kg}$ undigested DM in fecal excretion is required to compensate for the endogenous losses. In the NRC-2001 model, calculation of the MP value considers rumen endogenous protein passed on to the small intestine. It contributes to the total MP value. The rumen endogenous protein is associated with DM content. However, the NRC-2001 model does consider 
the endogenous protein losses in the small intestine, but it is added to requirements rather than subtracted from supply. This is a big difference.

Differences in Prediction of Ruminally Undegraded Feed Protein: The two models also differ in predicted ruminally undegraded feed protein. In the DVE/OEB system [18], the ruminally undegraded feed protein was calculated as: $1.11 \times \mathrm{CP} \times \mathrm{RUP}$. The factor 1.11 represents the regression coefficient of in vivo on in situ degradation data. However, using the NRC-2001 model, the ruminally undegraded feed CP was calculated as: $\mathrm{CP} \times \mathrm{RUP}$. No correction is made for the difference between in vivo and in situ results.

Differences in Prediction of Microbial Protein Supply Based on Ruminally Degraded Feed Protein: In the prediction of microbial protein availability and supply based on ruminally degraded feed protein, the two models are also different. In the DVE/OEB system [18], it is assumed that $100 \%$ ruminally degraded feed protein could be potentially converted to microbial protein if enough energy is provided. However, in the NRC-2001 model, it is assumed that only $85 \%$ of ruminally degraded feed protein could be potentially converted to microbial protein.

Differences in Prediction of the Truly Absorbed Intestinal Protein Contributed from the Ruminally Undegraded Feed Protein: To calculate truly absorbed protein in the small intestine contributed from the ruminally undegraded feed protein, the two models use different factor parameters. In the DVE/OEB system, the amount of truly absorbed rumen synthesized microbial protein in the small intestine was estimated as: $0.85 \times 0.75 \times \mathrm{MCP}_{\mathrm{FOM}}$. It assumes that true digestibility of microbial protein is $85 \%{ }^{[80]}$ (Egan et al., 1985 ) and $75 \%$ of microbial $\mathrm{N}$ is present in amino acids, the remaining is $\mathrm{N}$ in nucleic acids. In the NRC2001 model, both digestibility and true protein of ruminally synthesized microbial $\mathrm{CP}$ are assumed to be $80 \%$, therefore the amount of truly absorbed rumen synthesized microbial protein in the small intestine was estimated as: $0.80 \times 0.80 \times \mathrm{MCP}^{\mathrm{NRC}}$. Although the individual coefficients differ, the net result is essentially the same between the two models $(0.85 \times 0.75)$ vs. $(0.80 \times 0.80)$.

Differences in Prediction of Microbial Protein Synthesized in the Rumen Based on Available Energy: Both models could predict the potential microbial protein synthesized in the rumen based on available energy. The DVE/OEB system uses rumen fermented $\mathrm{OM}$ as energy base to predict microbial protein supply. However, the NRC-2001 model uses available TDN as energy base. This is another big difference. Each model also uses different factor parameters to calculate microbial protein synthesized in the rumen. In the DVE/OEB system, $150 \mathrm{~g}$ of microbial protein $\mathrm{CP}$ is assumed to be synthesized per $\mathrm{kg}$ fermented OM. But in the NRC-2001 model, it is assumed that $130 \mathrm{~g}$ of microbial protein $\mathrm{CP}$ is synthesized per $\mathrm{kg}$ TDN.

Degraded Protein Balance $-\mathbf{A}$ New Concept: The DVE/OEB system ${ }^{[18]}$ introduced a new concept - the role of energy balance in protein supply: the degraded protein balance. It can also be calculated based on data from the NRC-2001 model. The degraded protein balance (in the DVE/OEB system) shows the (im)balance between microbial protein synthesis from available rumen degradable $\mathrm{CP}$ and potential energy from anaerobic fermentation in the rumen. When the degraded protein balance is positive, it indicates the potential N-loss from the rumen. When negative, microbial protein synthesis is predicted to be impaired because of a potential shortage of $\mathrm{N}$ in the rumen. The optimum degraded protein balance value in a ration is therefore zero or slightly above ${ }^{[17,18]}$.

All of the above individual differences contribute to a difference in prediction of amount of total truly absorbed protein in the small intestine (DVE vs. MP) between the two models.

Limitations and Advantages of Modeling Nutrient Supply and Availability vs. In vivo Animal Trial: Both the DVE/OEB model and the NRC-2001 model are deterministic (not stochastic) and empirical and are based on several assumptions. For example, in the DVE/OEB model, $150 \mathrm{~g}$ of microbial protein is assumed to be synthesized per $\mathrm{kg}$ rumen fermented OM. In the NRC-2001 model, $130 \mathrm{~g}$ of microbial protein is assumed to be synthesized per $\mathrm{kg}$ TDN. Therefore potential nutrient supply, such as microbial CP supply based on nutrient intake in each group, does not vary a great deal in both two models. This is in contrast to microbial $\mathrm{CP}$ supply based on total purine derivative excretion $[83,84]$ or based on in vivo measurement ${ }^{[85]}$. This is because in vivo or purine derivative methods are relative measures of the real microbial CP production. They are affected by several factors such as ruminal $\mathrm{pH}$ and ruminal turnover rate and by individual animal variation ${ }^{[86,87]}$, not only nutrient intake. 
However, using the advanced models to estimate feed protein availability has a great advantage. The modeling feed protein nutritive data are not affected by some uncertain factors, such as climate, animal body condition, ration, temperatures. These factors always affect in vivo animal trial to estimate feed nutritive values. Also in vivo animal trial to estimate protein value is time-consuming, expensive and prone to errors within and between laboratories.

Applications of the DVE/OEB and NRC-2001 Models: The DVE/OEB and NRC-2001 models (feed nutritive evaluation model) have been used mainly for three purposes as follows: (1) Using the models to quantitatively predict the changes of the nutrient supply and availability from feeds affected heat processing [1, 5]; (2) Using the models to make it possible to determine the best and/or optimal heat processing condition [3, 88], and (3) Using the models to make it possible to predict best variety, best maturity stage and best processing for a feed ${ }^{[62,89]}$.

Using the Models to Determine Optimal Heat Processing and Predict Changes of the Nutrient Availability from Protein Feeds Affected by Heat Processing: Publications showed that heat processing does reduce ED and increase RUP (such as ${ }^{[90,91,92]}$ ), but none of them provide detailed how heat processing affected microbial protein synthesis and potential nutrient supply on a quantitative basis and none of them were optimal heating conditions identified. Heating above the optimal temperature may overprotect the protein so that the protein is neither fermented in the rumen nor digested in the small intestine ${ }^{[1,93]}$.

Legume seeds (lupin seeds, faba beans, peas and soybeans) have high ratio of available $\mathrm{N}$ to available carbohydrates [94], which is larger than $25-33 \mathrm{~g} \mathrm{~N} / \mathrm{kg}$ $\mathrm{DM}$ of optimum ratio, reported by Tamming et al. ${ }^{[7]}$. The soluble or rapidly degradable protein and starch of legume seeds is too high, resulting in unnecessary potential nutrient losses from the rumen. Yu et al. ${ }^{[3,95]}$ and Goelema ${ }^{[1]}$ have attempted to use the developed DVE/OEB model to predict potential microbial protein synthesis and potential nutrient supply to ruminants from four major legume seeds (faba beans, peas, lupin and soybean) affected by pressure toasting and dry roasting and to determine optimal processing conditions of pressure toasting and dry roasting of faba beans, lupin seeds, peas and soybeans in term of the protein DVE and OEB values to achieve target values for potential high net absorbable protein in the small intestine while holding any $\mathrm{N}$ loss in the rumen to a low level, using the DVE/OEB model. These studies were systematically evaluate the effects of heat treatments on rumen degradation and intestinal digestion characteristics of raw and heated legumes seeds at various conditions to give the quantitative aspects of how the heat treatments affecting the protein degradation and digestion in detail and provided information for ration formula and the decision for the optimal treatment conditions in dairy industry. The items assessed in those experiments were not only rumen degradation characteristics in terms of $\mathrm{S}, \mathrm{D}, \mathrm{U}$, Kd, T0, ED but also RUP, RUST, FOM, ARUP, E_MP, N_MP, TPSI, AMP, ENDP, DVE and OEB values. The most important values are potential protein DVE and OEB values, which were changed by heat processing for each legume seed. The results show the prediction of potential nutrient availability and supply to ruminants from raw and heated lupin seeds, faba beans, peas and soybeans by using the DVE/OEB model.

These studies indicated that pressure toasting significantly increased the predicted BUP (76 to 185 ; 47 to $148 ; 58$ to $149 ; 121$ to $189 \mathrm{~g} / \mathrm{kg}$ DM for lupin seeds, faba beans, peas and soybeans, respectively), increase RUSt (94 to $174 ; 158$ to $248 \mathrm{~g} / \mathrm{kg}$ DM for faba beans and peas; lupin seeds and soybeans contain little starch and no BSt was reported), increased true protein value of TPSI supplied to the small intestine (164 to $260 ; 121$ to $200 ; 136$ to $206 ; 186$ to $246 \mathrm{~g} / \mathrm{kg}$ DM for lupin seeds, faba beans, peas and soybeans, respectively), increased truly intestinal absorbed rumen undegradable protein value of ARUP (71 to $176 ; 40$ to $139 ; 54$ to $145 ; 102$ to $178 \mathrm{~g} / \mathrm{kg}$ DM for lupin seeds, faba beans, peas and soybean, respectively), and increased truly digested intestinal protein value of DVE (133 to $232 ; 89$ to $170 ; 115$ to $189 ; 152$ to $222 \mathrm{~g} / \mathrm{kg} \mathrm{DM}$ for lupin seeds, faba beans, peas and soybean, respectively). Pressure toasting decreased rumen fermented OM value of FOM, microbial protein value of E_MP synthesized in the rumen based on available energy, truly intestinal absorbed rumen synthesized microbial protein value of AMP, microbial protein value of N_MP synthesized in the rumen based on available $\mathrm{N}$ and degraded protein balance value of OEB with increasing temperature and time.

Though pressure toasting reduced microbial protein synthesis due to a reduction in FOM and a reduction in rumen protein degradation, the total truly digested intestinal protein value of DVE did not decrease but increased markedly. This was due to the fact that absorbable RUP value was highly increased more than enough to compensate for the computed decrease in microbial protein production. Therefore the net absorbable DVE value in the animal was substantially increased $(\mathrm{DVE}=$ ARUP+AMP-ENDP). 
The largest increase of the DVE value for all legume seeds investigated was found in $136^{\circ} \mathrm{C} / 15 \mathrm{~min}$ of pressure toasting, which highly increased the net absorbable protein DVE value $76,90,64$ and $45 \%$ for lupin seeds, faba beans, peas and soybeans, respectively, as AA source in the intestines.

When the OEB value of a feed is positive, it indicates the potential $\mathrm{N}$ loss from the rumen. When negative, microbial protein synthesis is predicted to be potential impaired because of a shortage of $\mathrm{N}$ in the rumen of this feed. The studies showed that raw lupin seeds, horse beans, peas and soybeans all had high OEB values $(142,101,88$ and $186 \mathrm{~g} / \mathrm{kg} \mathrm{DM}$, respectively), which indicated a potential imbalance between feed $\mathrm{N}$ degradation and utilization and indicated a potentially large N loss from rumen. Pressure toasting reduced the OEB values with increasing time and temperature, but did not cause them to become negative (142 to $44 ; 101$ to $32 ; 88$ to $25 ; 186$ to $128 \mathrm{~g} / \mathrm{kg} \mathrm{DM}$ for lupin seeds, horse beans, peas and soybeans, respectively). High positive OEB values in the most treatments except $136^{\circ} \mathrm{C}$ for $15 \mathrm{~min}$ for horse beans and peas indicated that there were still large potential losses of $\mathrm{N}$ in the rumen. In other words, the treatments of $100^{\circ} \mathrm{C} / 7,15$ or $30 \mathrm{~min}, 118^{\circ} \mathrm{C} / 3,7,15$ or $30 \mathrm{~min}$ and $136^{\circ} \mathrm{C} / 3$ or $7 \mathrm{~min}$ were not sufficient to reduce $\mathrm{N}$ loss in the rumen if they are used as rumen undegradable protein sources for high production ruminants.

The above results indicated that with pressure toasting, temperature and/or duration could go still higher than $136^{\circ} \mathrm{C}$ and/or longer than $15 \mathrm{~min}$ with soybeans and lupins (due to their high OEB values, 128.2 and $44.4 \mathrm{~g} / \mathrm{kg} \mathrm{DM}$, respectively) to further prevent potential $\mathrm{N}$ loss in the rumen if total tract digestion is not depressed. But pressure toasting up to $136^{\circ} \mathrm{C}$ for $15 \mathrm{~min}$ covered the optimal treatment range for peas and faba beans (under certain circumstances) in terms of treating to achieve target values for potential high net absorbable protein in the small intestine while holding any $\mathrm{N}$ loss in the rumen to a low level.

Yu et al. ${ }^{[95]}$ used the same approach by using the DVE/OEB model to predict changes of potential nutrient supply to ruminants from whole lupin seeds and whole faba beans after dry roasting at various conditions, which are commonly used for ruminants on farm basis in Australia and to determine the optimal dry roasting conditions under certain circumstances for whole lupin seeds and whole faba beans), and found that dry roasting of whole lupin seeds and whole faba beans increased RUP, RUSt, TPSI, ARUP and DVE values and decreased FOM, E MP, AMP, N MP and OEB with increasing temperature and time. Though dry roasting was effective in shifting protein degradation from rumen to intestine, and increased net absorbable protein DVE value, dry roasting up to $150^{\circ} \mathrm{C}$ for $45 \mathrm{~min}$ could not fully prevent potential $\mathrm{N}$ loss in the rumen for whole faba beans (due to the high OEB value). But dry roasting up to $150^{\circ} \mathrm{C}$ for $45 \mathrm{~min}$ of whole lupin seeds might cover the optimal treatment range due to its high net absorbable DVE value (increasing from 110 to 197 $\mathrm{g} / \mathrm{kg} \mathrm{DM}$ ) and lowest OEB value (reducing from 157 to $26 \mathrm{~g} / \mathrm{kg} \mathrm{DM}$ ).

In conclusion, legume seeds (lupin seeds, faba beans, peas and soybeans) have high ratio of available $\mathrm{N}$ to available carbohydrates $(>25-33 \mathrm{~g} \mathrm{~N} / \mathrm{kg}$ DM of optimum ratio). The soluble or rapidly degradable protein and starch of legume seeds is too high, resulting in unnecessary potential nutrient losses from the rumen. Heat processing has potential for application as an effective means to improve ruminal digestion and nutrient conservation of legume seed components. The site of digestion of starch and protein of legume seeds can also be manipulated by processing. Heat treatment (pressure toasting, dry roasting, extrusion etc) can reduce the rate and extent of rumen degradation of both protein and starch in legume seeds, thus resulting in a potential increase in the supply of protein (as AA source) and/or starch (as glucose source) to the small intestines. However, optimal processing conditions have not yet been established for individual legume seeds in terms of maximizing AA absorption in the small intestines. The advanced DVE/OEB model appears to have characteristics that can provide relatively accurate information on the quantitative aspects of both ruminal and post-ruminal feed protein digestion in ruminants for each feedstuff. With the DVE/OEB model, it is possible to predict the potential nutrient supply to the animal from the feeds as affected by heat processing.

Using the NRC-2001 Model and the DVE/OEB System to Predict Nutrient Availability of Harrington (Malting-Type) and Valier (Feed-Type) Barley Affected by Grinding Processing: Yu et al. ${ }^{[62]}$ used the DVE/OEB system and NRC-2001 mode to compare chemical characterization, rumen digestive kinetics of each feed component, and potential nutrient availability to ruminant animals between the maltingtype barley (cv. Harrington) and feed-type barley (cv. Valier), which were affected by coarse (Roller miller, $0.533 \mathrm{~mm}$ gap) and fine (Hammer mill, $2 \mathrm{~mm}$ screen) processing.

Using the DVE/OEB system to predict the potential nutrient availability found that using the coarse processing, Valier barley had significantly lower in truly absorbed microbial protein (AMCP: 35 vs. 53 $\mathrm{g} / \mathrm{kg} \mathrm{DM}$ ), but higher in truly absorbed rumen undegraded feed protein (ARUP: 69 vs. $47 \mathrm{~g} / \mathrm{kg} \mathrm{DM}$ ) and endogenous protein (ENDP: $25 \mathrm{vs.} 15 \mathrm{~g} / \mathrm{kg}$ DM) in the small intestine. However, total truly digested protein value (DVE) in the small intestine between two varieties was not significantly different (average of 83 $\mathrm{g} / \mathrm{kg} \mathrm{DM}$ ). Prediction results by the NRC 2001 model showed that using the coarse processing, Valier barley had significantly lower in AMCP (34 vs. $44 \mathrm{~g} / \mathrm{kg} \mathrm{DM}$ ), but higher in ARUP and similar in rumen endogenous protein (ECP: average $11 \mathrm{~g} / \mathrm{kg} \mathrm{DM}$ ), which resulting in a higher total metabolizable protein value (107 vs. 95 $\mathrm{g} / \mathrm{kg} \mathrm{DM}$ ) in Valier barley. Again when using the fine processing, all the predicted different effects 
disappeared. In conclusion, the study showed that Valier barley differed in chemical characterization and protein and carbohydrate fractions, but was similar in the estimated energy values in comparison with Harrington barley. Both varieties had negative protein degradation balance, indicating the potential imbalance between microbial protein synthesis from available rumen degradable $\mathrm{CP}$ and potential energy from anaerobic fermentation in the rumen. The nutritional characterization of Valier and Harrington barley were highly associated with processing method. In this study, using the coarse processing, Valier barley was significantly lower in rumen degradability of DM and $\mathrm{CP}$ and higher total MP value than Harrington barley. However, when using the fine processing, all the nutritive differences between the two varieties disappeared.

\section{CONCLUSIONS AND IMPLICATIONS}

In conclusion, this article reviewed three strategies to study protein internal structures and protein availability affected by heat processing. With newly emerging synchrotron light sourced FTIR microspectroscopy, the structural features and molecular chemistry of protein in tissues could be revealed and identified. The studies demonstrate the potential of highly spatially resolved synchrotron-based technique (S-FTIRM) as a novel tool to localize relatively pure protein and reveal inherent protein structure which were affected by heat processing. The CNCPS system make it able to reveal the effects of heat processing on profile changes of protein subfractions associated with digestive behaviors and kinetics, manipulated by heat processing methods. The changes of the proportions of these protein fractions influence the amounts of ruminally degraded and escape protein consumed by animals. The advanced NRC-2001 model and DVE/OEB model appears to have characteristics that can provide relatively accurate information on the quantitative aspects of both ruminal and post-ruminal protein digestion. With the two models, it is possible to predict the potential nutrient availability and supply as affected by heat processing. These two models can also be used to determine the best and/or optimal processing conditions and overheating and underheating on quantitative basis. The establishment of a complex protein evaluation system using the above three strategies, plus the newly emerging synchrotron-based analytical technique will more accurately accounts for protein digestive processes affected by heat processing on a quantitative basis.

\section{ACKNOWLEDGMENTS}

The author wish to thank Drs. S. Tamminga and J. Goelema in Wageningen University, The Netherlands; Drs. A. Egan and B. Leury in the University of Melbourne, Australia and Dr. J.J. McKinnon and D.A. Christensen in the University of
Saskatchewan, Canada for helpful discussion during previous studies. The synchrotron-based feed research work has been supported by grants from Natural Sciences and Engineering Research Council of Canada (NSERC) and Saskatchewan Agricultural Development Fund (ADF). The National Synchrotron Light Source in Brookhaven National Laboratory (NSLS-BNL, New York, USA) is supported by the U.S. Department of Energy contract DE-AC02-98CH10886. The Synchrotron Radiation Center (SRC, University of Wisconsin, Madison) is supported by the NSF under Award No. DMR-0084402. The Center for Proteomics at Case Western Reserve University is supported by the National Institute for Biomedical Imaging and Bioengineering under P41-EB-01979. The synchrotronbased feed and ruminant nutrition work was done in cooperation with Drs. J.J. McKinnon, D.A Christensen and C.R. Christensen (Canadian Light Source). The author is grateful to Drs. Marinkovic, N.S., Miller, L.M., J. Bohon, A. Ignatov and Wang, Qi at NSLSBNL (New York, USA) and Dr. Robert Julian at Port 031 (Synchrotron Radiation Center, University of Wisconsin, Madison) for helpful data collection at the synchrotron stations, Dr. K.M. Gough (University of Manitoba) for helpful discussion and valuable suggestions and Director V. Racz (Feed Resource Center), Drs. B. Rossnagel, P. Thacker, H. Soita and R. Newkirk (University of Saskatchewan) for supplying samples.

\section{REFERENCES}

1. Goelema, J.O., 1999. Processing of legume seeds: effect on digestive behavious in dairy cows. Ph.D Thesis. Wageningen Agricultural University, The Netherlands.

2. 2. Goelema, J.O., A. Smits, L.M. Vaessen, and A. Wemmers, 1999. Effects of pressure toasting, expander treatment and pelleting on in vitro and in situ parameters of protein and starch in a mixture of broken peas, lupins and faba beans. Anim. Feed Sci. Technol., 78: 109-126.

3. 3. Yu, P., J.O. Goelema, and S. Tamminga, 2000. Determination of optimal conditions of pressure toasting on horse beans for dairy feed industry, by the DVE/OEB model. Anim. Feed Sci. Technol., 86: $165-176$.

4. 4. Yu, P., M. Sprague, A.R. Egan, G.H. Castleman, and B.J. Leury, 2001a. Comparison of raw and roasted narbon beans (Vicia narbonensis) on performance and meat sensory attributes of lambs fed a roughage-based diet. Anim. Feed Sci. Technol., 92: 1-16.

5. 5. Yu, P., J.O. Goelema, B.J. Leury, S. Tamminga, and A.R. Egan, 2002a. An analysis of the nutritive value of heat processed legume seeds for animal 
production using the DVE/OEB model: A review. Anim. Feed Sci. Technol., 99: 141-176.

6. Van der Poel, A.F.B., J. Blonk, D.J. van Zuilichem, and M.G. van Oort, 1990. Thermal inactivation of lectins and trypsin inhibitor activity during steam processing of dry beans (Phaseolus vulgaris) and effects on protein quality. J. Sci. Food Agric., 53: 215-228.

7. Tamminga, S., A.M. van Vuuren, C.J. van der Koelen, R.S. Ketelaar, and P.L. van der Togt, 1990. Ruminal behavior of structural carbohydrates, non-structural carbohydrates and crude protein from concentrate ingredients in dairy cows. Neth. J. Agric. Sci., 38: 513-526.

8. Soita, H.W., J.A. Meier, M. Fehr, P. Yu, D.A. Christensen, J.J. McKinnon, and A.F. Mustafa, 2003. Effects of flaxseed supplementation on milk production, milk fatty acid composition and nutrient utilization by lactating dairy cows. Arch. Anim. Nutr., 57: 107-116.

9. Holum, J.R., 1982. Fundamentais of General, Organic, and Biological Chemistry. $2^{\text {nd }} E d n, J$. Wiley and Sons, Inc., New York, NY.

10. Yu, P., J.J. McKinnon, H.W. Soita, C.R Christensen, and D.A. Christensen, 2005a. Use of synchrotron-based FTIR microspectroscopy to determine protein secondary structures of raw and heat treated brown and golden flaxseeds: a novel approach. Can. J. Anim. Sci., 85: 437-448

11. Seguchi, M., M. Takemoto, U. Mizutani, M. Ozawa, C. Nakamura, and Y. Matsumura, 2004. Effects of secondary structures of heated egg white protein on the binding between prime starch and tailings fractions in fresh wheat flour. Cereal Chem., 81: 633-636.

12. Yu, P., 2005a. Protein secondary structures $(\alpha-$ helix and $\beta$-sheet) at a cellular level and protein fractions in relation to rumen degradation behaviors of protein: a novel approach. Bri. J. Nutr., 94: 655-665

13. Yu, P., S. Tamminga, A.R. Egan, AND D.A. Christensen, 2004a. Probing equivocal effects of heat processing of legume seeds on performance of ruminants - a review. Asian-Austr. J. Anim Sci., 17: 869-876.

14. Yu, P., 2004. Application of advanced synchrotron-based Fourier transform infrared microspectroscopy (SR-FTIR) to animal nutrition and feed science: a novel approach. Bri. J. Nutri., 92: 869-885.

15. Yu, P., 2006. Synchrotron IR Microspectroscopy for Protein Structure Analysis: Potential and
Questions: A Review. Spectroscopy, 20: 229-251 (Invited Review Article: Dr. P.I. Haris Editor-inChief, UK).

16. Sniffen, C. J., J.D. O'Connor, P.J. Van Soest, D.G. Fox, and J.B. Russell, 1992. A net carbohydrate and protein system for evaluating cattle diets: II. Carbohydrate and protein availability. J. Anim. Sci., 70: 3562-3577.

17. Tamminga, S., and A.J.M. Jansman, 1993. Animal Nutrition (Ed: B.A. Williams). Wageningen Agricultural University, The Netherlands

18. Tamminga, S., W.M. Van Straalen, A.P.J. Subnel, R.G.M. Meijer, A. Steg, C.J.G. Wever, and M.C. Block, 1994. The Dutch protein evaluation system: the DVE/OEB-system. Livest. Prod. Sci., 40: 139155.

19. NRC, 2001. Nutrient requirement of dairy cattle. $7^{\text {th }}$ rev. ed. National Research Council, Washington, D.C.: National Academy Press.

20. Yu, P., J.J. McKinnon, C.R. Christensen, and D.A. Christensen, 2003a. Mapping plant composition with synchrotron infrared microspectroscopy and relation to animal nutrient utilization. Proc. The Canadian Society of Animal Science - 2003 Conference. University of Saskatchewan, Saskatoon, SK, Canada, June 10-13, pp: 1-20 (Invited Article and Conference Speech).

21. Yu, P., J.J. McKinnon, C.R. Christensen, and D.A. Christensen, 2004b. Using synchrotron-based FTIR microspectroscopy to reveal chemical features of feather protein secondary structure: comparison with other feed protein sources J. Agric. Food Chem., 52: 7353-7361.

22. McAllister, T.A., R.C. Phillippe, L.M. Rode, and K.J. Cheng, 1993. Effect of the protein matrix on the digestion of cereal grains by ruminal microorganisms. J. Anim. Sci., 71: 205-212.

23. Yu, P., D.A. Christensen, C.R. Christensen, M.D. Drew, B.G. Rossnagel, and J.J. McKinnon, 2004c. Use of synchrotron FTIR microspectroscopy to identify chemical differences in barley endosperm tissue in relation to rumen degradation characteristics. Can. J. Anim. Sci., 84: 523-527.

21. Dyson, H.J., and P.E. Wright, 1990. Peptide conformation and protein folding. Current Opinion in Structural Biology., 3: 60-65.

25. Carey, F.A., 1996. Organic Chemistry. $3^{\text {rd }}$ Edition. McGraw-Hill Companies, Inc.

26.Dumas, P., 2003. Synchrotron IR Microspectroscopy: A Multidisciplinary Analytical Technique. The 6th Annual Synchrotron CLS Users' Meeting and Associated Synchrotron 
Workshops - WinXAS and Infrared. University of Saskatchewan, Canada. Nov 13-15, 2003.

27. Budevska, B.O., 2002. Applications of Vibrational Spectroscopy in Life, Pharmaceutical and Natural Sciences. In: Handbook of Vibrational Spectroscopy (eds J.M. Chalmers and P.R. Griffiths), Vol. 5. New York: John Wiley and Sons, Inc. pp: 3720-3732.

28. Stewart, D., G.J. McDougall, and A. Baty, 1995. Fourier transform infrared microspectroscopy of Anatomically Different Cells of Falx (Linum usitatissimum) stems during development. J. Agric. Food Chem., 43: 1853-1858.

29. NRC, 1996. Nutrient Requirement of Beef cattle ( $7^{\text {th }}$ Ed). National Research Council, Washington, D.C., National Academy Press.

30. Weiss, W.P., H.R. Conrad, and N.R.S. Pierre, 1992. A theoretically-based model for predicting total digestible nutrient values of forages and concentrates. Anim. Feed Sci. Technol., 39: 95110 .

31. Yu, P., D.A. Christensen, J.J. McKinnon, and H.W. Soita, 2004d. Using chemical and biological approaches to predict energy values of selected forages affected by variety and maturity stage. Asia-Austral. J. Anim. Sci., 17: 228-236.

32. Synchrotron facts, $2003 . \quad$ Available: http://www.cls.usask.ca/students/whatis.php.

Accessed Apr, 2003.

33. Wetzel, D.L., A.J. Eilert, L.N. Pietrzak, S.S. Miller, and J.A. Sweat, 1998. Ultraspatially resolved synchrotron infrared microspectroscopy of plant tissue in situ. Cell. Mol. Bio., 44: 145-167.

34. Raab, T.K., and M.C. Martin, 2001. Visualizing rhizosphere chemistry of legumes with midinfrared synchrotron radiation. Planta, 213: 881887.

35. Miller, L.M., 2000. The impact of infrared synchrotron radiation on biology: past, present, and future. Synchrotron Radiation News, 13: 31-37.

36. Miller, L.M., 2002. Infrared Microsperctroscopy and Imaging. Retrieved in October 2002 from http://nslsweb.nsls.bnl.gov/nsls/pubs/nslspubs/imag ing0502/irxrayworkshopintroduction.ht

37. Marinkovic, N.S., R. Huang, P. Bromberg, M. Sullivan, J. Toomey, and L.M. Miller, 2002. Sperber, E.; Moshe, S.; Jones, K. W.; Chouparova, E.; Lappi, S.; Franzen S.; Chance, M. R. Center for Synchrotron Biosciences' U2B beamline: an international resource for biological infrared spectroscopy. J. Synchrotron Rad., 9: 189-197.
38. Miller, L.M., C.S. Carlson, G.L. Carr, and M.R. Chance, 1998. A Method for Examining the Chemical Basis for Bone Disease: Synchrotron Infrared Microspectroscopy. Cell. Mol. Bio., 44: 117-127.

39. Wetzel, D.L., 2001. When molecular Causes of wheat quality are known, molecular methods will supercede traditional methods. Proc. Int'l Wheat Quality Conf. II, Manhattan, Kansas, USA, pp: 120.

40. Bonetta, D.T, M. Facette, T.K. Raab, and C.R. Somerville, 2002. Genetic dissection of plant cellwall biosynthesis. Biochemical Society Transactions, 30: 298-301

41. Vogel, J.P., T.K. Raab, C. Schiff, and S.C. Somerville, 2002. PMR6, a pectate lyase-like gene required for powdery mildew susceptibility in Arabidopsis. Plant Cell, 14: 2095-2106.

42. Yu, P., J.J. McKinnon, C.R. Christensen, D.A. Christensen, N.S. Marinkovic, and L.M. Miller, 2003b. Chemical imaging of micro-structures of plant tissues within cellular dimension using synchrotron infrared microspectroscopy. J. Agric. Food Chem., 51: 6062-6067

43. Yu, P., J.J. McKinnon, C.R. Christensen, and D.A. Christensen, 2004e. Using synchrotron transmission FTIR microspectroscopy as a rapid, direct and non-destructive analytical technique to reveal molecular microstructural-chemical features within tissue in grain barley. J. Agric. Food Chem., 52: $1484-1494$.

44. Yu, P., J.J. McKinnon, C.R Christensen, and D.A. Christensen. 2004f. Imaging molecular chemistry of pioneer corn. J. Agric. Food Chem., 52: 73457352.

45. Yu, P. 2005b. Molecular chemistry imaging to reveal structural features of various plant feed tissues. J. Structural Biol., 150: 81-89

46. Himmelsbach, D.S., S. Khalili, and D.E. Akin, 1998. FT-IR microspectroscopic imaging of flax (linum usitatissimum L.) stems. Cell. Mol. Bio., 44: 99-108.

47. Jackson, M., and H.H. Mantsch, 2000. Infrared spectroscopy Ex Vivo Tissue Analysis. In: Bimedical Spectroscopy.

48. Mantsch, H.H and D. Chapman, 1996. Infrared Spectroscopy of Biomolecules. Wiley-Liss. New York.

49. Kemp W., 1991. Organic Spectroscopy. $3^{\text {rd }}$ ed. W.H. Freeman and Company, New York, USA.

50. Martin, M.C., 2002. Fourier-Tranform Infrared Spectroscopy.

Available: http://infrared.als.lbl.gov/. Accessed Oct, 2002. 
51. Wetzel, D.L., P. Srivarin, and J.R. Finney, 2003. Revealing protein infrared spectral detail in a heterogeneous matrix dominated by starch. Vibrational Spectroscopy, 31: 109-114.

52. Holman Hoi-Ying, N., K.A. Bjornstad, M.P. McNamara, M.C. Martin, W.R. McKinney, and E.A. Blakely, 2002. Synchrotron infrared spectromicroscopy as a novel bioanalytical microprobe for individual living cells: cytotoxicity considerations. J. Biomedical Optics., 7: 1-10.

53. Cytospec, 2004. Software for infrared spectral imaging. V. 1.1.01

54. Yu, P., C.R. Christensen, D.A. Christensen, and J.J. McKinnon. 2005b. Ultrastructural-chemical makeup of yellow- (Brassica Rapa) and brownSeeded (Brassica Napus) canola within cellular dimensions, explored with synchrotron reflection FTIR microspectroscopy. Can. J. Plant Sci., 85: 533-541.

55. Yu, P. 2005c. Feed protein inherent structures at a cellular level in relation to protein value in animals: comparison between yellow- (Brassica Rapa) and brown-seeded (Brassica Napus) canola. Bri. J. Nutr. In Review.

56. Kauppinen, J.K., D.J. Moffatt, H.H. Mantsch, and D.G. Cameron, 1981. Fourier selfdeconvolution: a method for resolving intrinsically overlapped bands. Applied Spectroscopy., 35: 271-276.

57. Griffths, P.R., and G. Pariente, 1986. Trends in Analytical Chemistry in Introduction to Spectral Deconvolution, Vol 5, pp: 209.

58. Yu, P. 2005d. Multi-component peak modeling of protein secondary structures: comparison of Gaussian with Lorentzian analytical method for plant feed and seed molecular biology and chemistry research. Applied Spectroscopy, 59: 1372-1380.

59. Yu, P., 2005e. Application of cluster analysis (CLA) in feed chemical imaging to accurately reveal structural-chemical features of feeds within cellular dimension. J. Agric. Food Chem., 53: 2872-2880.

60. Yu, P., 2005f. Applications of cluster analysis (CLA) and principal component analysis (PCA) in feed structure and feed molecular chemistry research using synchrotron-based FTIR microspectroscopy. J. Agric. Food Chem., 53: 7115-7127.

61. Sockalingum, G.D., W. Bouhedja, P. Pina, P. Allouch, C. Bloy, and M. Manfait, 1998. FT-IT spectroscopy as an emerging method for rapid characterization of microorganisms. Cellular and Molecular Biology., 44: 261-269.

62. Yu P., J. Meier, D.A. Christensen, B. Rossnagel, and J.J. McKinnon, 2003c. Using the NRC-2001 model and the DVE/OEB system to evaluate nutritive values of Harrington (malting-type) and Valier (feed-type) barley for ruminants. Anim. Feed Sci. Technol., 107: 45-60.

63. Nocek, J.E., and S. Tamminga, 1991. Site of digestion of starch in the gastrointestinal tract of dairy cows and its effect on milk yield and composition. J. Dairy Sci., 74: 3598-3629.

64. Givens, D.I., P. Clark, D. Jacklin, A.R. Moss, and C.R. Savery, 1993. Nutritional aspect of cereal, cereal grain by-products and cereal straw for ruminants. HGCA Research Review 24, pp: 1-180. Home-grown Cereal Authority, Hamlyn House, Highgate Hill, London, England.

65. Gibson, L.A., J.G.P. Bowman, L.E. Oberthur, and T.K. Blake, 1994. Determination of genetic markers associated with ruminant digestion of barley. Proc Western Section, American Society of Animal Science. V 45.

66. Bowman, J.G.P., T.K. Blake, L.M.M. Surber, D.K. Habernicht, T.K. Daniels, and J.T. Daniels, 2001. Genetic factors controlling digestibility of barley for ruminants. Proc. Western Section, American Society of Animal Science. Available: http://hordeum.oscs.monatan.edu/

cowdocs/cow596.htm. Accessed June, 2001.

67. Wang, Y., and T.A. McAllister, 2000. Grain processing for ruminants: latest technologies. Proc. the Twenty-First Western Nutrition Conference. Winnipeg, Manitoba, Sept. 28-29.

68. Yu, P., 2005g. Using synchrotron infrared microspectroscopy as a rapid, direct and nondestructive analytical technique to reveal micostructural-chemical features of feed/food/plant tissues at a cellular and subcellular level. Proceedings of the $96^{\text {th }}$ AOCS (American Oil Chemists Society) Annual Meeting and Expo - Salt Palace Conventional Center, Salt Lake City, Utah, USA, May 1-4, 2005, pp: 41-42 (Invited Conference Article and Speech).

69. Elizalde, J.C., N.R. Merchen, and D.B. Faulkner, 1999. Fractionation of fiber and crude protein in fresh forages during the spring growth. J. Anim. Sci., 77: 476-484.

70. Chaudhry, A.S., and A.J.F. Webster, 1993. The true digestibility and biological value for rats of undegraded dietary nitrogen in feeds for ruminant. Anim. Feed. Sci. Technol. 42: 209-221.

71. Rebolé, A., J. Treviño, R. Caballero, and C. Alzueta, 2001. Effect of maturity on the amino acid profiles of total and nitrogen fractions in common vetch forage. J. Sci. Food Agric., 81: 455-461.

72. INRA, 1978. Alimentation des ruminants. In: Inst. National de al Rech. Agron. Versailles, pp: 597 
73. Vérité, R., and Y. Geay, 1987. Evaluation and implementation of the PDI system in France. Pages 249-261 in Feed valuation and protein requirement systems for ruminants. R. Jarrige, and $\mathrm{G}$. Aldeirman, ed. ECSC-EEC-EAEC. Brussels.

74. ARC, 1984. The Nutrient Requirement of Ruminant Livestock. Suppl. No. 1. Commonwealth Agricultural Bureaux, Slough, England, pp: 45.

75. NKJ-NJF, 1985. Introduction of the Nordic protein evaluation system for ruminants into practice and future research requirements. Proposals by the NKJ-NJF protein group. Acta Agric. Scand., 25 (Suppl.): 216-220.

76. Madsen, J., 1985. The basis for the proposed Nordic protein evaluation system for ruminants. The AATPBV system. Acta. Agri. Scand. (Suppl.), 25: 9-20.

77. NRC, 1985. Ruminant nitrogen usage. Page 138 in National Academy Press. Washington D.C.

78. Varhegyi, J., J. Schmidt, E. Cenkvari, and J. Varhegyi, 1998. Comparison of the new Hungarian protein evaluation system for ruminants with foreign systems. Allattenyesztes es Takarmanyozas, 47: 239-246.

79. Muia, J.M.K., S. Tamminga, P.N. Mbugua, J.N. Kariuki, 2001. Rumen degradation and estimation of microbial protein yield and intestinal digestion of napier grass (Pennisetum purpureum) and various concentrates. Anim. Feed Sci. Technol., 93: 177-192.

80. Egan, A.R., K. Koda, and K. Barady, 1985. Regulation of $\mathrm{N}$ metabolism and recycling. In: Control of digestion and metabolism in ruminants. Pages 146-153 in Proc. $6^{\text {th }}$ International Symposium on Ruminant Physiology. Butterworths, Londdon.

81. CVB, 1996. Centraal Veevoeder Bureau. Voorlopig protocol voor in sacco pensincubatie voor het meten van eiwitbestendigheid, 14 November.

82. Yu, P., 2005h. Prediction of protein supply to ruminants from concentrates: comparison of the NRC-2001 model with the DVE/OEB system. J. Sci. Food Agric., 85: 527-538

83. Yu, P., L. Boon-ek, B.J. Leury, and A.R. Egan, 2001b. Effect of dietary protein variation in terms of net truly digested intestinal protein (DVE) and rumen degraded protein balance (OEB) on the concentrations and excretion of urinary creatinine, purine derivatives and microbial $\mathrm{N}$ supply in sheep: comparison with the prediction from the DVE/OEB model. Anim. Feed Sci. Technol., 93: 71-91

84. Yu, P., A.R. Egan, L. Boon-ek, and B.J. Leury. 2002b. Purine derivative excretion and ruminal microbial yield in growing lambs fed raw and dry roasted legume seeds as protein supplements. Anim. Feed Sci. Technol., 95: 33-48.
85. De Boever, J.L., N. Iantcheva, B.G. Cottyn, S. De Campeneere, L.O. Fiems, and CH. V. Boucque, 1998. Microbial protein synthesis in growingfinishing bulls estimated from the urinary excretion of purine derivatives. Anim. Feed Sci. Technol., 75: 93-109.

86. Hoover, W.H., and S.R. Stokes, 1991. Balancing carbohydrates and proteins for optimum rumen microbial yield. J. Dairy Sci., 74: 3630-3644.

87. Moscardini, S., T.C. Wright, P.H. Luimes, B.W. McBride, and P. Susmel, 1998. Effects of rumenundergradable protein and feed intake on purine derivative and urea nitrogen: comparision with predictions from the Cornell Net Carbohydrate and Protein System. J. Dairy Sci., 81: 2421-2429.

88. Yu, P., A.R. Egan, B.J. Leury, J.J. McKinnon, and D.A. Christensen. 2004g. Nutrient supply to dairy cows from processed white lupines. Arch. Anim. Nutr., 58: 117-135.

90. Cros, P, C. Benchaar, C. Bayourthe, M. Vernay, and R. Moncoulon, 1991. In situ evaluation of the ruminal and intestinal degradability of extruded whole lupin seed nitrogen. Reprod. Nutr. Dev., 31: 575-583.

91. Cros, P., M. Vernay, C. Bayourthe, and R. Moncoulon, 1992. Influence of extrusion on ruminal and intestinal disappearance of amino acids in whole horse bean. Can. J. Anim. Sci., 72: 359-366.

92. Benchaar, C., M. Vernay, C. Bayourthe, and R. Moncoulon, 1994. Effects of extrusion of whole horse beans on protein digestion and amino acid absorption in dairy cows. J. Dairy Sci. 77: 13601371.

93. Stern, M.D., K.A. Santos, and L.D. Satter, 1985. Protein degradation in rumen and amino acids absorption in the small intestine of lactating dairy cattle fed heat-treated whole soybeans. J. Dairy Sci., 68: 45-56.

94. Yu, P., 1999. Improvement and evaluation of nutrient utilization in legume seeds by dry roasting in ruminants. University of Melbourne, Australia.

95. Yu, P., A.R. Egan, and B.J. Leury, 1999. Protein evaluation of dry roasted whole faba bean and lupin seeds by the new Dutch protein evaluation system: the DVE/OEB system. Asian-Austr. J. Anim Sci., 12: 871-880. 